Division of Geological \& Geophysical Surveys

PUBLIC-DATA FILE 94-51

\title{
PRELIMINARY WATER RESOURCE ASSESSMENT OF THE GIRDWOOD AREA, ALASKA
}

\author{
by \\ Stan Carrick and Mary Maurer \\ Alaska Department of Natural Resources \\ Division of Mining and Water Management \\ Alaska Hydrologic Survey \\ in cooperation with \\ Alaska Department of Natural Resources \\ Division of Land
}

September 1994

THIS REPORT HAS NOT BEEN REVIEWED FOR

TECHNICAL CONTENT (EXCEPT AS NOTED IN TEXT) OR FOR CONFORMITY TO THE EDITORIAL STANDARDS OF DGGS.

Released by

STATEOPALASKA

DEPARTMENT OFNATURALRESOURCES

Division of Geological \& Geophysical Surveys

794 University Avenue, Suite 200

Fairbanks. Alaska 99709-3645 


\section{CONTENTS}

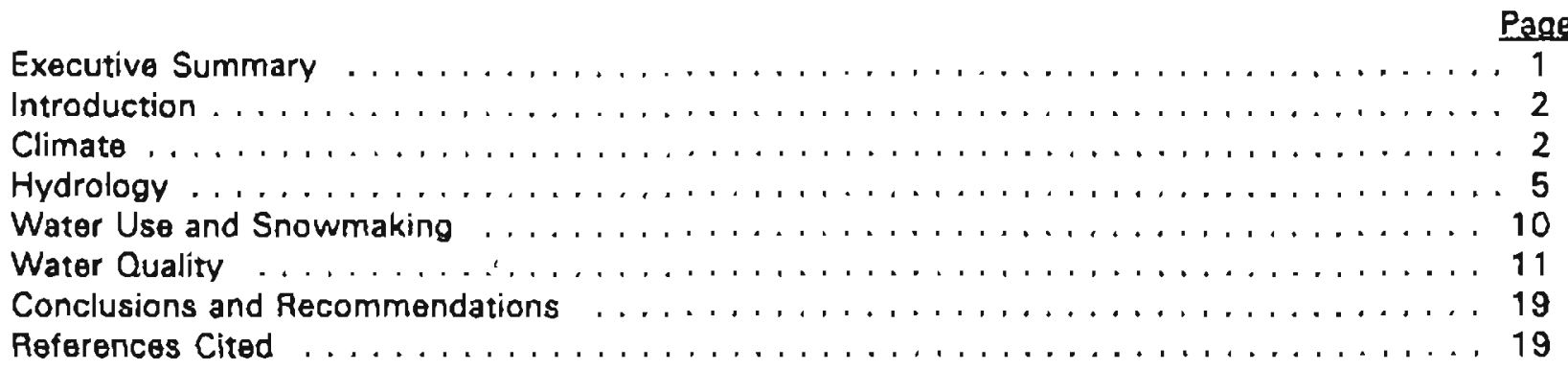

\section{FIGURES}

Figure 1. Location of hydrologic data collection sites and water-quality sampllng sites . . . . . 3 Figure 2. Glacier Creek mean monthly flow . . . . . . . . . . . . . . . . . . . 8

Figure 3. Trilinear diagram of Glacier and Winner Creek waters . . . . . . . . . . . 17

\section{TABLES}

Table 1. Mt. Alyeska mean monthly snow depth . . . . . . . . . . . . . . . . . . 4

Table 2. Glacier Creek basin physical characteristics . . . . . . . . . . . . . . . 6

Table 3. Glacier Creek flood statistics ... . . . . . . . . . . . . . . . . . . . 6

Table 4. Streamflow data for upper Glacier, Winner, and Crow Creeks . . . . . . . . . . . . 9

Table 5. Upper Glacier Creek basin monthly mean flow calculations . . . . . . . . . . . . . . 10

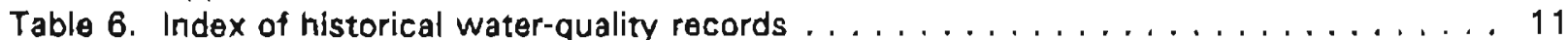

Table 7. On-site water-quality measurements $\ldots \ldots \ldots \ldots \ldots \ldots \ldots \ldots \ldots$

Table 8. Summary of suspended sediment and turbidity data . . . . . . . . . . . . . . 14

Table 9. Results from laboratory analyses for inorganic constituents . . . . . . . . . . 15

Table 10. Potential impacts associated with development in the project area . . . . . . . . 18

\section{APPENDICES}

Appendix A. Glacier Creek drainage basin streamflow data . . . . . . . . . . . . . 22

Appendix B. Laboratory water-quality analytical reports . . . . . . . . . . . . . . . 23 


\section{EXECUTIVE SUMMARY}

Glacier Creek, $30 \mathrm{mi}$ southeast of Anchorage, drains $58 \mathrm{sq} \mathrm{mi}$ of glaciated terrain sandwiched between the Chugach Mountains to the north and Turnagain Arm to the south. The community of Girdwood lies in the lower Glacier Creek valley adjacent to the Alyeska Resort. Alaska Hydrologic Survey hydrologists collected climate, streamflow, and water quality data for Glacier Creek, Winner Creek, and Crow Creek to provide information for the Alaska Department of Natural Pesources' Turnagain Arm Management Plan. The potential development of a four-season resort in the Glacier/Winner Creek area has prompted planners to investigate and document baseline conditions in the area.

The general climate of the upper Glacier/Winner Creek valley is similar to the climate at the Alyeska Resort. Winter brings moderate temperatures, and rair mixed with snow at elevations below 1000 ft. Above the $1000 \mathrm{ft}$ snowline, temperatures usually stay below treezing and snowfall is heavy. At the midway point of the Alyeska Resort, $1540 \mathrm{ft}$ elevation, annual total snowfall averages 455 in., while maximum snow depth on the ground averages 110 in. The same general weather conditions exist at the Glacier/Winner area, except the base is 200-300 ft higher than Alyeska, meaning more skiable acreage is subject to below-freezing temperatures and snow instead of rain, Snowmaking on the lower Glacier Winner slopes would be necessary to sustain a good snow base for early season skiing. The upper Glacier/Winner area is also more wind-affected than the Alyeska Resort ski slopes.

Surface water is abundant In the Glacier Creek drainage most of the year. Mid- to late-winter prolonged cold temperatures can result in low flows in any of the area streams. Potential impacts to the amount of flow in Glacies. Winner, and Crow Creeks would come from domestic usage and snowmaking withdrawals. In early April 1992, low flows in each stream ranged from 3.2 to 8.4 million gallons per day (mgpd) or 5-13 cubic feet per second (cfs). Domestic water needs for the proposed resort development are approximately $0.53 \mathrm{mgpd}$ or $0.8 \mathrm{cfs}$; these needs could be met by using groundwater from additional wells drilled in the Glacier Creek valley downstream. Snowmaking water needs for November through January are roughly $0.36 \mathrm{mgpd}$ or $0.6 \mathrm{cfs}$, and could be met by withdrawals from Glacier, Crow, and Winner Creeks.

Water-quality findings are based on data collection in the autumn of 1992, and mid-and late-winter of 1993. All three streams had low temperatures, high oxygen concentrations, basic $\mathrm{pH}$, and low hardness values. Total suspended sediment concentrations and turbidity were low in all three streams during the winter. Glacier and Winner Creeks have low total dissolved solids and calcium bicarbonate type water. Most of the laboratory-analyzed inorganic constituents and trace elements did not exceed the maximum contaminant levels (MCL)s listed in the Alaska Drinking Water Regulations. Aluminum, iron, and manganese slightily exceeded MCLs.

The most probable water-quality impacts to Glacier, Winner, and Crow Creeks are an increase in the suspended-sediment load and turbidity associated with land development and road construction. The potential for sediment runoff is high at the confluence of these streams because of the precipitous terrain and shallow soils. Introduced suspended sediment will be most noticeable in late autumn and winter when streams are virtually free of glacial silt. Erosion and runoff control measures will be required to lessen impacts of recreational land development on surface waters. 


\section{INTRODUCTION}

Hydrologists from the Alaska Department of Natural Resources (DNR), Division of Mining and Water Management, Alaska Hydrologic Survey (AHS) collected data on streamflow, water-quality, and climate for the Glacier, Winner, and Crow Creek basins as part of the DNR, Division of Land (DOL) Turnagain Arm Management Plan. Proposed resort development in the Glacier/Winner Creek area is the primary purpose for the baseline data collection effort. Baseline data are used to identify predevelopment conditions so potential impacts from development can be assessed and mitigated more effectively.

Girdwood, Alaska, and the Alyeska Resort are located $30 \mathrm{mi}$ southeast of Anchorage, and lie 2-3 mi downstream of the confluence of Glacier, Winner, and Crow Creeks (fig. 1). Girdwood lies in a broad, glacial valley surrounded by mountains up to $6500 \mathrm{ft}$ elevation to the north, and Turnagain Arm at sea level to the south. In 1992 Girdwood had a stable population of approximately 1300 , but that number increases with by the seasonal influx of winter skiers and summer tourists.

This report presents climate summaries taken from various sources, surface and ground water information from the U.S. Geological Survey (USGSI and AHS, and water-quality data derived from the USGS, Municipality of Anchorage (MOA), and AHS. Surface-water quantity and quality data were collected by AHS from April 1992 to February 1994. The hydrologic deta are not complete, however, and additional quantity and quality data will need to be collected before a comprehensive analysis of baseline conditions and development impacts is possible.

\section{CLIMATE}

Girdwood is situated in a transitional climate zone, subject to both maritime and interior weather. Low-pressure storms from the Gulf of Alaska bring cloudy, wet weather to Girdwood, while high pressure from the north will occasionally result in strerches of clear, dry weather that can persist for weeks. Weather records compiled by the Arctic Environmental Information and Data Center (AEIDC, 1986) show Girdwood' with an average temperature of $36^{\circ} \mathrm{F}$, mean annual precipitation of $40 \mathrm{in}$., and mean annual snowfall of $129 \mathrm{in}$. The warmest month is July with temperatures typically in the 60's, while the coldest month is December when temperatures usually range from $15-25^{\circ} \mathrm{F}$. Late summer and fall is the wettest time of year in Girdwood, while May and June are driest.

Mountain weather varies with elevation. Higher elevations are characterized by cooler temperatures, increased precipitation, and higher winds. For Mt. Alyeska, the Soil Conservation Service (1993) reports an average annual precipitation of 69 in. at the midway station, nearly a $75 \%$ increase over the annual precipitation measured at the Girdwood site discussed above.

Snowfall differences with increasing elevation are even more striking. At the base (300 ft) of the Alyeska ski area, average annual total snowfall is $144 \mathrm{in.,}$ at midwav (1540 ft) the average annual snowfall is $455 \mathrm{in}$., and at the top of the lift-serviced area $(2800 \mathrm{ft})$ the total annual snowfall averages 527 in. (Seibu Alaska, 1991). The disparity between the base and midway snowfall totals results from the snowline that lies at approximately $1000 \mathrm{ft}$ elevation. Below that level, winter high temperatures are often above freezing, causing rain; above $1000 \mathrm{ft}$, normally subfreezing temperatures produce snow.

Table 1 gives average snow depths at the midway site for the 1973-1991 period-of-record, as provided by SCS (1992).

\footnotetext{
'Weather data for Girdwood was collected at the Dept. of Transportation highway maintenance office near the Seward Highway, at $20 \mathrm{tt}$ elevation.
} 


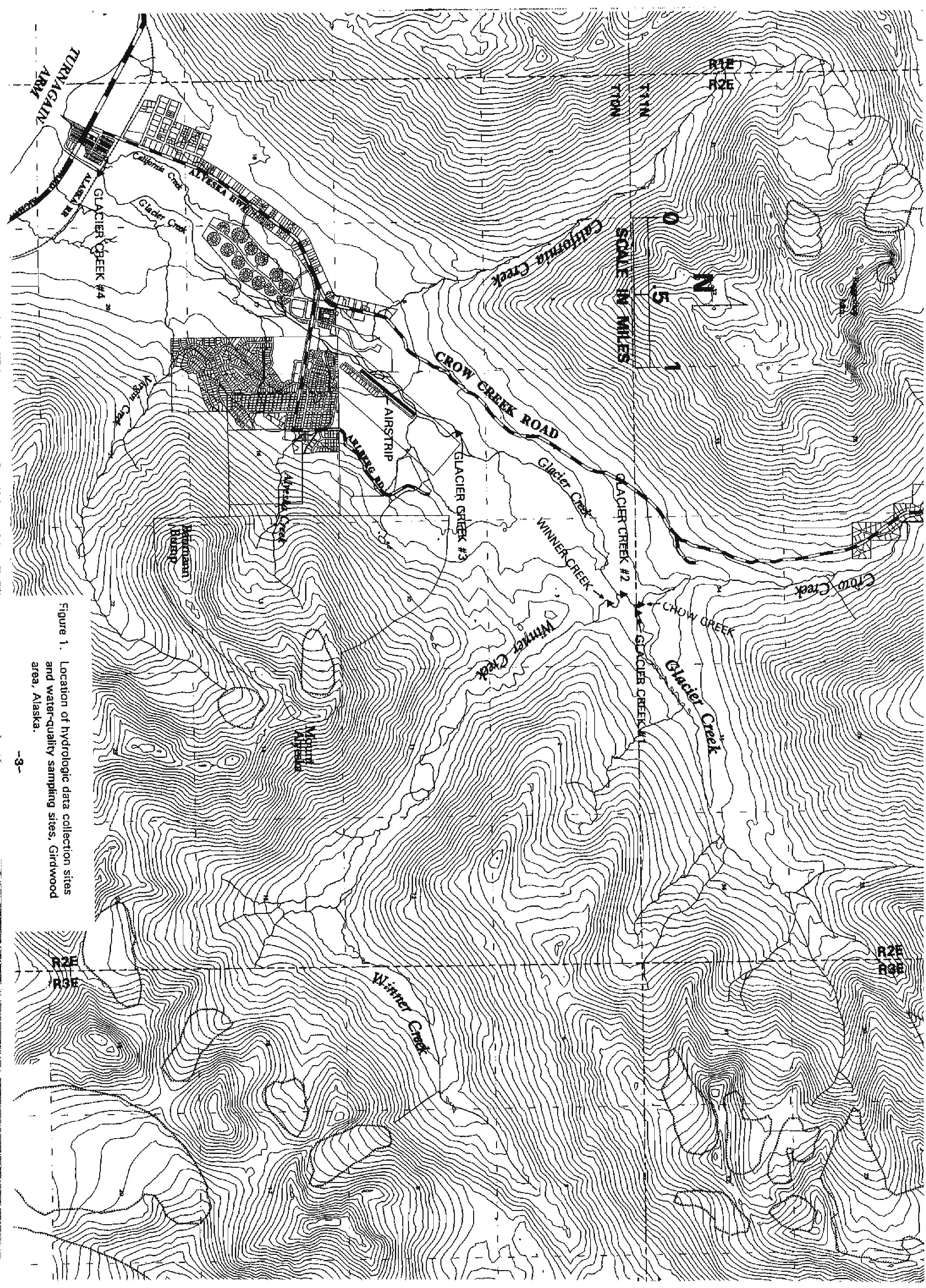


Table 1. Mt. Alyeska average monthly snow depth at midway $(1540 \mathrm{ft})$.

\begin{tabular}{l|c|c} 
Month & Average Snow Depth (in.) & Water Equivalent (in.) \\
\hline \hline February 1 & 78 & 23 \\
\hline March 1 & 95 & 30 \\
\hline April 1 & 109 & 36 \\
\hline May 1 & 110 & 41
\end{tabular}

Wind data are not complete for the area. The general wind patterns are dependent on the dominant pressure system at the time. Low pressure systems commonly bring warmer temperatures, precipitation, and winds out of the east or southeast down Turnagain Arm. High pressure systems are associated with cold temperatures, dry conditions, and winds out of the north or northeast.

The mountainous terrain in the Girdwood area complicates the general wind patterns. Locally, winds can be channeled and intensified down valleys in different directions than the dominant winds aloft. Dense, cold air can also move down from higher elevation glaciers to the valley floors creating significant, strong gusts of wind. The highest winds at Alyoska in the winter typically originate with high pressure systems from the northeast (Seibu Alaska, 1991). Low pressure systems from the southeast don't affect Alyeska in the winter as much as the high pressure systems, because Mt. Alyeska and Max's Mountain to the east and above the ski area effectively diminish the stronger winds.

\section{Glacier/Winner Creek Climate}

GlacierMinner Creek weather is similar to Mt. Alyeska's, with a few exceptions. The base elevation of the proposed ski area would be 500-650 ft, compared to an elevation of $300 \mathrm{ft}$ at Alyeska. In addition, the Glacier Winner base is $2.5 \mathrm{mi}$ farther away from the moderating influence of the marine waters of Turnagain Arm. Consequently, base temperatures at Glacier/Winner are slightly cooler than Alyeska, resulting in less rain and more snow at the proposed area.

Miscellaneous snow depth measurements taken from 1981-1986 (Seibu Alaska, 1986) at both base sites showed the GlacierMinner base area to have approximately $55 \%$ greater snow depth, on average, than the Alyeska base.

Higher elevation snow depth comparisons between the two areas do not correlate with the differences in base snow depths. Miscellaneous snow depth measurements taken on the same dates as above, show Alyeska as having greater snow depths than Glacier/Winner over a range of similar elevations above $1000 \mathrm{ft}$. The lighter snowpack on the Glacier/Winner upper slopes could be a result of a combination of factors, such as drier air at a greater distance from Turnagain Arm, terrain differences and exposure, and wind effects.

Wind affects the lower slopes of both the Glacier/Winner area and Mt. Alyeska similarly: generally light to moderate wind with relatively insignificant snow movement. The upper slopes of Glacier/Winner experience greater wind velocities and more snow movement than the Mt. Alyeska ski slopes. According to the U.S. Forest Service (1986), the top of the Glacier/Winner area shows heavy cornicing throughout the winter, and cornices developed within the ski basin down to an Glevation of $1800 \mathrm{ft}$. 
The prevailing direction for the cornice-producing winds is east-northeast. Where the steep, upper slopes of Mt. Alyeska provide some protection to ski runs from east-northeast winds, topography and orientation expose the Glacier/Winner area to more wind. The upper ridges of the Glacier/Winner slopes are more rounded, and that can lead to more spillover of high winds. The generally northeast-southwest alignment of Glacier Creek means the nearby slopes will also be more impacted by a northeast wind than Mt. Alyeska would. The lighter snowpack and higher winds of the Glacier/Winner area are not insurmountable problems if ski runs and lifts are appropriately designed and located, and if proper operational maintenance is provided.

\section{HYDROLOGY}

\section{Ground Water}

Ground water information for the Girdwood area is limited, and site-specific oata for the Glacier/Winner area does not exist. AHS did not evaluate the ground-water potential for this study, but the USGS in 1974 published a report that addressed the occurrence and availability of ground water in the Girdwood area (Zenone, 1974).

Aquifers in the Glacier Creek valley are found in subsurface layers of sand and gravel deposited by Glacier Creek and its tributaries. Most of the wells in Girdwood are drilled into the alluvium of Glacier Creek, or the alluvial fans of California and Alyeska Creeks. Ground water was encountered at depths of $40-80 \mathrm{ft}$ in these wells, with an average vield of 20 gallons per minute $(\mathrm{gpm})$. Approximately six other wells (along Glacier Creek near the airstrip and at the Alyeska Creek alluvial fan) have higher yields of 200-500 gpm (Zenone, 1974).

Private and public wells supply nearly all the water for domestic, commercial, and industrial uses in Girdwood. The Anchorage Water and Wastewater Utility (AWWU) provides water for the east side of Glacier Creek including Alyeska Resort and the Alyeska Prince Hotel. Glacier Utilities supplies water to users west of Glacier Creek. Twenty-four percent of Girdwood homes rely on private wells (Waring, 1993). The combined capacity of the iwo public systems, AWWU and Glacier Utilities, is approximately $1000 \mathrm{gpm}$ or 1.44 million gallons per day, equivalent to $2.2 \mathrm{cts}$ (Municipality of Anchorage, 1993\}.

No wells exist upstream of the AWWU wells that are situated 0.5 mi northeast of the airstrip near Glacier Creek. Above this point, the floodplain of Glacier Creek narrows from nearly $1000 \mathrm{ft}$ to less than $100 \mathrm{ft}$ upstream of the confluence with Crow and Winner Creeks. The slopes of the valley sides steepen and become bedrock gorges immediately downstream of the confluence. Consequently, the alluvial deposits are narrowly confined and thin, and may not be adequate for any significant ground-water production.

Any ground water supplies for the proposed Glacier/Winner resort would have to come from existing wells or from additional wells drilled in the vicinity of or downstream of the AWWU wells northeast of the airstrip. It is estimated (Sno.engineering, 1993) that a new resort could need up to 534,000 gallons per day (gpd), or $0.83 \mathrm{cfs,} \mathrm{of} \mathrm{water} \mathrm{for} \mathrm{domestic} \mathrm{use.} \mathrm{Ground} \mathrm{water} \mathrm{yields} \mathrm{in}$ the Glacier Creek valley should be sufficient to supply the domestic needs of a new resort without significantly impacting existing wells. If necessary, onsite water storage can augment well yields during periods of peak demand and for fire protection.

\section{Surface Water}

Glacier Creek is the largest drainage basin in the Girdwood Valley. The stream heads at the termini of numerous glaciers in the Chugach Mountains, $8 \mathrm{mi}$ northeast of the mouth on Turnagain Arm. Table 2 gives physical characteristics of Glacier Creek compiled by Lamke (1979). 
Table 2. Glacier Creek dralnage basin physical characteristics.

\begin{tabular}{c|c|c|c|c|c|c|c} 
Drain. Basin & $\begin{array}{c}\text { Stream } \\
\text { Area (sq mi) }\end{array}$ & $\begin{array}{c}\text { Channel } \\
\text { Slope } \\
\text { (ft/mi) }\end{array}$ & $\begin{array}{c}\text { Mean Basin } \\
\text { Elev. (ft) }\end{array}$ & $\begin{array}{c}\text { Mean } \\
\text { Area of } \\
\text { Forest (\%) }\end{array}$ & $\begin{array}{c}\text { Mean } \\
\text { Area of } \\
\text { Glacier (\%) }\end{array}$ & $\begin{array}{c}\text { Annual } \\
\text { Basin Ppt. } \\
\text { (in.) }\end{array}$ & $\begin{array}{c}\text { Basin } \\
\text { Snow. (in.) }\end{array}$ \\
\hline \hline 58.2 & 11 & 455 & 2610 & 28 & 11 & 80 & 160
\end{tabular}

Tributaries (with drainage basin areas in sq mi) to Glacier Creek include: Upper Glacier Creek (14.6), Crow Creek (12.6), Winner Creek (12.6), California Creek (8.9), Moose Meadow Creek $(1.6)$, and Alyeska Creek (1.2). See Figure 1. Another stream, Virgin Creek (3.0), heads at a perennial snowfield on the south side of Mt. Alyeska, but flows into Turnagain Arm not Glacier Creek.

Surface water is abundant in the Glacier Creek valley most of the year. Streamflow in the valley can be characterized as having lowest flows in late winter, increasing flow during spring breakup, highest streamflow in June and July when glacier and snowfield melt is at a peak, and declining flows in the fall. Meltwater from glaciers and snowfields augments streamflow throughout the non-winter months. Flooding can occur from hot weather and rapid snowmelt during spring and early summer, or more typicaliy as a result of runoff during heavy rains in late summer and fall. Cold, dry weather in mid- to late-winter causes extreme low flows in valley streams.

\section{Previous work}

Three sources of published information exist on streamflow in the Glacier Creek valley.

1) The Corps of Engineers (1969) prepared a document for the (then) Anchorage Borough, entitled, "Flood Plain Information, Glacier Creek, Girdwood, Alaska." This report discusses flood potential and maps the floodplain of Glacier Creek from the north end of the airstrip downstream to the Seward Highway. Most flooding on Glacier Creek occurs as a result of intense rainfall on top of the normal background flow.

The peak measured flood on Glacier Creek was 7710 cubic feet per second (cfs) on September 18, 1967, a flow that approximates the 13-year flood (U.S. Geological Survey, 1978). During this time, water rose to the steps of the Girdwood post office and eroded the southern end of the airstrip. According to the Corps of Engineers (1969), Glacier Creek rose at a maximum rate of $0.3 \mathrm{ft}$ per hour and remained above flood stage of $6.2 \mathrm{ft}$ for 27 hours on September 17-18, 1967. Table 3 gives flood statistics for Glacier Creek (Corps of Engineers, 1969\}.

Table 3. Glacier Creek flood statistics.

\begin{tabular}{c|c|c|c|c|c} 
Location & $\begin{array}{c}\text { Streambed } \\
\text { Elevation (ft) }\end{array}$ & $\begin{array}{c}\text { Road Elevation } \\
\text { (ft) }\end{array}$ & $\begin{array}{c}1967 \text { Flood } \\
\text { Elevation (ft) }\end{array}$ & $\begin{array}{c}\text { Highest } \\
\text { Elevation (ft) }\end{array}$ & $\begin{array}{c}\text { Expected Flood } \\
\text { Elev. (ft) }\end{array}$ \\
\hline \hline $\begin{array}{c}\text { Seward } \\
\text { Highway }\end{array}$ & 12 & 30.4 & Unknown & 25.0 & 27.0 \\
\hline $\begin{array}{c}\text { Alyeska } \\
\text { Highway }\end{array}$ & 101 & 118.8 & 108.0 & 111.7 & 114.0 \\
\hline \hline Hlow (cfs) & N/A & N/A & 9,710 & 14,000 & 26,000
\end{tabular}


For a flood of the approximate magnitude of the 50-year flood or greater, high water can be expected from the airstrip downstream to Turnagain Arm, with a floodplain width of up to $0.6 \mathrm{mi}$ between the Alyeska and Seward Highways. At these higher flows, Glacier Creek erosion would be widespread, and according the Corps of Engineers (1969) a 100-year flood could produce flood waters $3-4 \mathrm{ft}$ deep in the vicinity of the Girdwood post office. Above the airstrip, flood waters would be confined to the narrower and deeper channel of Glacier Creek. Tributary streams could produce flooding in proportion to the high flows on Glacier Creek. Floods less than a 50-year magnitude can still produce localized erosion and property damage.

2) In 1974, the U.S. Geological Survey published a report authored by C. Zenone, and entitled, "Geology and Water Resources of the Girdwood-Alyeska Area. Alaska." This report summarized the geology of the Glacier Creek valley, and gave an overview of area hydrology including ground water, water quality, and surface water resources.

3) Glass and Brabets (1988) published flow statistics and water quality for Glacier Creek at the USGS gage site, along with miscellaneous streamflow measurements taken on Glacier, California, and Virgin Creeks. In addition, the report reviewed ground water hydrology and water quality for the area, including results of three new test wells drilled at Girdwood.

4) The USGS (1965-1992) gaged Glacier Creek at the Alaska Railroad bridge continuously from 1965-1978, and took miscellaneous low and high flow measurements from 19851987. Average annual runoff from the Glacier Creek drainage basin for the period-of-record is 58 in. Figure 2 shows a graph of summarized streamflow data for Glacier Creek. California Creek has been gageo at the Alyeska Highway by the USGS discontinuously from 1967-1992. The USGS also did a few miscellaneous flow measurements on Virgin Creek from 1985-1987. California Creek flow ceases during prolonged cold spells, while a low, but sustained, baseflow exists in Virgin Creek during the winter months IGlass and Brabets, 1988).

Other unpublished streamflow data exists for the Girow wood area. The MOA has investigated streams near Girdwood, and private consultants have undertaken studies of local streams for Seibu Alaska, Inc.

\section{Alaska Hydrologic Survey Streamflow Data}

AHS studied streamflow conditions on three streams in the Girdwood area: Glacier Creek, Crow Creek, and Winner Creek. The stuory was done in cooperation with the Alaska Division of Land, for the Turnagain Arm Management Plan. All three streams are potentially affected by any development in the upper Glacier Creek valley. The primary objective of this part of the study was to characterize the quantity of flow from the above three streams in order to extrapolate potential impacts to flow from water withdrawals.

A total of eleven discharge measurements were conducted on the three streams near their confluence, and two measurements were done at two different sites on Glacier Creek downstream of the confluence. A Marsh-McBirney flowmeter was used to measure velocity, and all streams were waded to make the measurements. No discharge measurements were conducted from May to September because the water was too high and fast to wade the streams during that time. Budget restrictions precluded the use of installing continuous gaging instruments. Table 4 summarizes the streamflow data gathered by AHS from April 1992 to February 1994. 


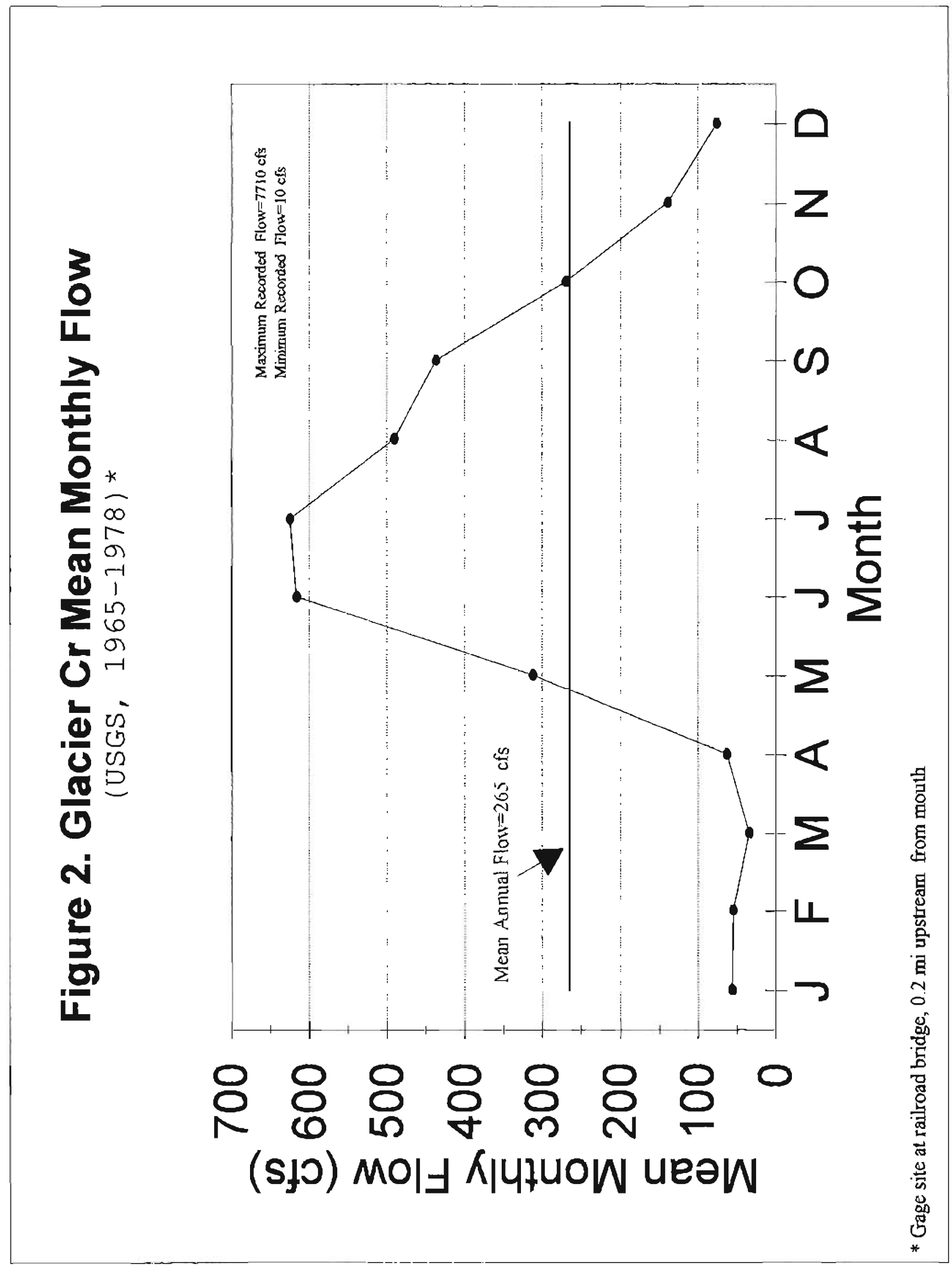


Table 4. Streamflow data for upper Glacier, Winner, and Crow Creeks.

\begin{tabular}{c|c|c|c|c|c} 
Site & Date & Flow (cfs) & Width (ft) & $\begin{array}{c}\text { Average Depth } \\
\text { (ft) }\end{array}$ & $\begin{array}{c}\text { Average } \\
\text { Velocity (ft/sec) }\end{array}$ \\
\hline \hline Glacier Cr \#1 & $4 / 7 / 92$ & 6.9 & 9.4 & 1.1 & 0.6 \\
(see fig. 1) & $1 / 13 / 93$ & 10 & 20.4 & 0.6 & 0.8 \\
& $4 / 14 / 93$ & 18 & 20.5 & 0.7 & 1.1 \\
\hline Crow Cr & $4 / 7 / 92$ & 4.8 & 13.1 & 0.6 & 0.6 \\
(see fig. 1) & $1 / 13 / 93$ & 8.6 & 9.2 & 1.0 & 0.8 \\
& $4 / 14 / 93$ & 15 & 10.0 & 1.1 & 1.0 \\
\hline \multirow{2}{*}{ Winner Cr } & $4 / 1 / 92$ & 12 & 21.5 & 0.6 & 0.8 \\
(see fig. 1) & $1 / 13 / 92$ & 110 & 29.0 & 1.5 & 2.3 \\
& $4 / 14 / 93$ & 15 & 25.5 & 1.1 & 0.6 \\
Glacier Cr \#2 & $9 / 1 / 92$ & 425 est & 30.0 & 1.2 & 0.9 \\
\hline
\end{tabular}

NOTE: Two miscellaneous flow measurements were taken downstream on Glacier Creek during the study. On December 9, 1992, the flow at a site 0.5 mi upstream of the airstrip (see fig. 1, Glacier Creek \#3) was $68 \mathrm{cfs}$, and on February 23, 1994 the flow was $34 \mathrm{cfs}$. No flow measurements were conducted at any of the upper gage sites during this time, because of difficult access.

On April 14, 1993, one measurement was conducted at the old USGS Alaska Railroad bridge gage site (see fig. 1, Glacier Creek \#4). The flow at this location was $118 \mathrm{cfs}$, compared to a combined flow of $60 \mathrm{cfs}$ at the three upper valley sites earlier that same day (see table 4 above). The difference in flow between the upper valley sites and the railroad bridge site can be attributed to contributions from California, Moose Meadow, and Alyeska Creeks, as well as any ground-water inputs. Temperatures in the lower valley on April 14 were above freezing, therefore the lower basin may have contributed proportionately more flow to Glacier Creek at the railroad bridge than the cooler higher elevation sites up the valley.

As a check of the partial data AHS collected, USGS (1965-1978) and Orsborn and Storm (1991) are used to fill in data gaps for the three upper valley measurement sites. The USGS flow data for Glacier Creek at the railroad bridge reflects flow conditions for the entire basin upstream. The flow data on record for the site can be converted to quantity of flow, or runoff per unit area for the drainage basin. For a relatively small, uniform basin like the Glacier Creek drainage, the runoff figures can be extrapolated to the smaller, similar tributary basin areas upstream. Orsborn and Storm (1991) use a model to estimate flow in ungaged streams.

Table 5 presents the results of the USGS and Orsborn and Storm data comparisons for the critical low-flow months of November-April. The flow figures calculated in table 5 favorably correlate to flow measurements taken by AHS during comparable months (see table 4). Table 5 (and app. 1) flow estimates can be used for general planning and design purposes where average or typical flow conditions are of interest. 
Table 5. Upper Glacier Creek basin monthly mean flow calculations.

\begin{tabular}{c|c|c|c|c|c|c|c} 
Site & Method & $\begin{array}{c}\text { Nov Mean } \\
\text { Flow (cfs) }\end{array}$ & $\begin{array}{c}\text { Dec Mean } \\
\text { Flow (cfs) }\end{array}$ & $\begin{array}{c}\text { Jan Mean } \\
\text { Flow (cfs) }\end{array}$ & $\begin{array}{c}\text { Feb Mean } \\
\text { Flow (cfs) }\end{array}$ & $\begin{array}{c}\text { Mar Mean } \\
\text { Flow (cfs) }\end{array}$ & $\begin{array}{c}\text { Apr Mean } \\
\text { Flow (cfs) }\end{array}$ \\
\hline Glacier Cr & USGS & 35 & 19 & 14 & 14 & 8.5 & 16 \\
$\# 1$ & R10 & 50 & 29 & 22 & 16 & 14 & 19 \\
\hline \multirow{2}{*}{ Crow Cr } & USGS & 30 & 16 & 12 & 12 & 7.3 & 14 \\
& R10 & 42 & 25 & 18 & 14 & 12 & 16 \\
\hline \multirow{2}{*}{ Winner Cr } & USGS & 30 & 16 & 12 & 12 & 7.3 & 14 \\
& A10 & 40 & 23 & 17 & 13 & 12 & 15
\end{tabular}

NOTE: "USGS" figures are based on runoff per sq mi data (USGS, 1965-1978), while "R10" figures are based on the Orsborn and Storm (1991) model. Crow and Winner Creeks have similar sized drainage basins and basin characteristics, thus the results are approximately equal. May-Oct mean flows are not included because flows are higher and adequate for ski area use then. Appendix A gives a complete table of USGS and Orsborn and Storm figures.

\section{WATER USE AND SNOWMAKING}

One of the primary concerns for developing a ski resort is winter water supply. Domestic consumption, fire protection, and snowmaking needs can depress water supplies during the typical winter low-flow period. Sno.engineering (1993), DNR and MOA's consultant on ski area planning, estimates a maximum domestic water demand of $534,000 \mathrm{gpd}$ or $0.83 \mathrm{cfs}$ for the proposed ski area. In addition, the consultant estimates snowmaking for the lower ski slopes could require an estimated 360,000 gpo or $0.56 \mathrm{cfs}$. The maximum total potential water needs for the proposed Glacier/Winner ski resort during the high demand winter months is 894,000 gpd or $1.4 \mathrm{cfs}$.

The lowest flow measured by the USGS $(1965-1978)$ for the entire Glacier Creek basin was 10 cfs on March 24, 1977. The three upper valley drainage basins comprise $68.5 \%$ of the total Glacier Creek watershed, so these sites could have contributed approximately $7 \mathrm{cfs}$ to the total $10 \mathrm{cfs}$ of the measured Glacier Creek flow. In other words, each upper valley tributary basin could have had an approximate flow of 1.5-2.5 cfs during late March of 1977. Using Orsborn and Storm's (1991) model for comparison, the 7-day, 20-year recurrence interval low flow for the upper Glacier Creek site is $3.4 \mathrm{cts}$, while the same flow for both Crow and Winner Creeks would be $2.9 \mathrm{cfs}$, for a total flow of $9.2 \mathrm{cfs}$.

From the low-flow calculations above, it is apparent that upper Glacier Cresk can experience extreme low flows on the order of $3 \mathrm{cfs}$, while Crow and Winner Creeks could experience extreme lows of approximately $2 \mathrm{cfs}$ each. Water for peak domestic and/or snowmaking needs taken from the upper valley tributaries during extreme low-flow periods, could impact instream flows for fish habitat or any downstream water users.

Average or typical winter low-flow conditions of 5-10 cfs in each upper valiey tributary, should meet the potential water supply demands of the proposed resort, without significant impacts to flow conditions downstream. A properly designed water storage and distribution system using a combination of surface and ground water, should alleviate any possible water supply difficulties experienced during extreme cold winter weather and low streamflow. 


\section{WATER QUALITY}

\section{Scope of Work}

The Alaska Department of Natural Resources, DOL requested the AHS to collect stream waterquality data in Glacier, Winner, and Crow Creeks to document conditions upstream of present development and near proposed future development within the drainage basin. These data are necessary to fill data gaps and to evaluate potential water-quality impacts associated with proposed recreational land development within the project area.

This report presents and evaluates the onsite and laboratory water-quality data collected in the 1) gorge area -- at the confluence of Glacier, Crow, and Winner Creeks, and 2) mainstem of Glacier Creek near the airstrip (fig. 11. Water samples were taken in autumn (September 1992), midwinter (December 1992 and January 1993), and late winter (April 1993). In addition, this report gives an index to the historical water-quality data for streams in the project area, and lists potential water-quality impacts associated with land development.

\section{Previous Investigations}

A comprehensive literature and data search was not undertaken because of budgetary restraints. An examination of the available information revealed that water-quality data have been collected for streams within the project area (table 6). The U.S. Geological Survey (USGS) data are tabulated in numerous water-data reports (USGS, 1958a; 1958b; 1967-69; 1971a; 1971b; $1972-$ 75; 1977b; 1979; 1986; 1988). The USGS data are summarized in a water resource report of the Girdwood-Alyeska area (Zenone, 1974; Glass and Brabets, 1988). More recently, the

Table 6. Index of historlcal water-quality records for surface waters in the project area.

\begin{tabular}{|c|c|c|c|c|c|}
\hline \multirow[b]{2}{*}{ Stream name } & \multirow[b]{2}{*}{ Station 10} & \multicolumn{3}{|c|}{ Type of water-quality data } & \multirow{2}{*}{$\begin{array}{c}\text { Data } \\
\text { coliector }\end{array}$} \\
\hline & & Sediment & Chemical & Microbiological & \\
\hline $\begin{array}{l}\text { Glacier Creek } \\
\text { at Girowood }\end{array}$ & 15272550 & $1966-74$ & $\begin{array}{l}1956: 66-72 ; \\
76-78: 85-86\end{array}$ & 1986 & USGS' \\
\hline $\begin{array}{l}\text { Glacier Creek } \\
\text { near airstrip }\end{array}$ & GLC 2000 & $1988-90$ & $1988-90$ & $1988-90$ & MOA 2 \\
\hline $\begin{array}{l}\text { Glacier Creek } \\
\text { at Seward Hwy. }\end{array}$ & GLC 1000 & $1988-90$ & 1988.90 & $1988-90$ & $\mathrm{MOA}^{2}$ \\
\hline $\begin{array}{c}\text { California Creek } \\
\text { at Girdwood }\end{array}$ & 15272530 & & $\begin{array}{c}1971-72 i \\
85-86\end{array}$ & 1985 & USGS $^{1}$ \\
\hline $\begin{array}{c}\text { California Creek } \\
\text { near Alaska } \\
\text { Aailroad Bridge }\end{array}$ & GLC 1010 & $1988-90$ & $1988-90$ & $1988-90$ & $\mathrm{MOA}^{2}$ \\
\hline $\begin{array}{l}\text { Milk Creek } \\
\text { at road bridge } \\
\text { near Girdwood }\end{array}$ & $\begin{array}{c}610146 \\
149064700\end{array}$ & 1953 & & & USGS' \\
\hline
\end{tabular}

I USGS = U.S. Geological Survey, Water Aesources Division, Anchorage, Alaska

2 MOA $=$ Municipality of Anchorage, Department of Health and Human Services 
Municipality of Anchorage, Department of Health and Human Services (DHHS), Division of Environmental Services (DES) collected water-quality data for Girdwood area streams from 1988 to 1990. These data are maintained in an unpublished database at the DHHS/DES office in Anchorage, Alaska (Marc Little, DHHS, oral commun., 1993\}.

\section{Field Sampling Procedures}

Although no quality-assurance plan was written prior to sampling, field measurements and water samples were taken in general accordance with the methods of the U.S. Geological Survey (1977a). Several onsite water-quality measurements were made at the three stream sites. Water temperature, dissolved oxygen concentration, and specific conductance were measured with a model-4041 Hydrolab that was pre- and post-calibrated according to the instrument's operation and maintenance instructions (Hydrolab, 1981). The stream pH was measured with either a Hydrolab or a Beckman $\Phi 11 \mathrm{pH}$ meter that was calibrated on-site with standard buffers. Total alkalinity was determined by potentiometric titration with Gran's graphical methods (Stumm and Morgan, 1981). Total hardness was determined with a model-HA-OT test kit, manufactured by Hach Company, of Loveland, Colorado. Turbidity was determined with a Hach model-16800 PortaLab turbidimeter.

Water samples for laboratory analysis of turbidity and suspended-sediment concentrations were collected by dip sampling. Depth-integrated sampling was not attempted in September 1992 because Glacier Creek was unwadable. Dip sampling was also conducted at Winner Creek to maintain sampling technique consistency and stream comparisons. Dip sampling, turbulence and suspected bedload movement in Glacier Creek probably introduced some error in the turbidity and suspended sediment measurements in September 1992. Dip sampling is less of a factor during the mid-winter and late-winter sampling trips when turbidity and suspended sediment loads are very low.

Water samples for laboratory analysis of inorganic constituents and trace elements were collected from Glacier and Winner Creeks in September 1992. Water samples were collected by dip sampling, and then composited in and split from a churn splitter. Both streams were well-mixed, thus a dip sample is a representative sample for inorganic constituent analysis. Water was collected by dipping a 1 -liter plastic bottle below the water surface. The bottle contents were then poured into a eight-liter capacity churn splitter. About six liters of water were obtained using this technique. Water was obtained about 5 feet from the water's edge in Glacier Creek and near midchannel in Winner Creek.

The composited water sample in the churn splitter was split into a set of four water samples per site in the following order: total trace elements (unfiltered), dissolved trace elements and cations (filtered), anions (filtered), and nutrients (filtered). The sample bottles for total trace element samples were filled at the churn splitter's spigot while operating the churn, to ensure the water samples were well-mixed. The filtered samples were split from the churn splitter with an inline filtration system. Water was drawn from the churn splitter with a MASTERFLEX hand pump equipped with silicone tubing. The water was forced through the tubing into a 142-mm GEOTECH filter assembly containing a $0.45-\mu m$ membrane filter. The filtrate from the filter assembly was collected in the sample bottles. The filter assembly was flushed with approximately $500-\mathrm{ml}$ of filtrate prior to bottle filling.

Water samples requiring on-site acidification were collected in bottles that were precharged with preservative acid. All samples were placed in a cooler and chilled with blue ice packs during transport to the laboratory. Samples were stored at $4^{\circ} \mathrm{C}$ in the laboratory until analyzed. 


\section{Laboratory Analyses}

Water-quality analyses were conducted at the AHS Water Quality Laboratory at the University of Alaska Fairbanks campus. The laboratory is a participant in the U.S. Environmental Protection Agency (USEPA) Performance Evaluation program as well as the USGS Standard Reference Water Quality Assurance program. Analytical methods and detection limits are listed on the analytical reports (app. B). For each constituent analyzed, laboratory instruments were calibrated using National Bureau of Standards traceable standards, where applicable. General data reduction procedures are described in Standard Methods (APHA, 1989).

Digestions for "total" metals were carried out using USEPA methods (EPA, 1983). Samples for total metals are reduced and refluxed with several additions of acid before returning the sample to its original volume, which results in a thorough and complete digestion of the sample.

Holding times, as described by USEPA (1983) and Standard Methods (APHA, 1989), were not exceeded for any of the samples.

\section{Results and Discussion}

Field measurements and onsite test results are shown on table 7. The three streams have low water temperatures, high dissolved oxygen concentrations, and basic $\mathrm{pH}$. Specific conductance ranged from 70 to $133 \mu \mathrm{S} / \mathrm{cm}$. Glacier and Winner Creeks have total hardness values of 58 and 48 $\mathrm{mg} / \mathrm{l}$, respectively. Water having a hardness value less than $60 \mathrm{mg} / \mathrm{l}$ is considered soft, 61-120 $\mathrm{mg} / \mathrm{l}$ is considered moderately hard, and 121-180 is considered hard (Hem, 1985).

Table 7.

On-site water-quality measurements made in area streams during 1992 and 1993.

\begin{tabular}{|c|c|c|c|c|c|c|c|c|}
\hline Stream site' & Dere & $\begin{array}{l}\text { Water } \\
\text { Temp. } \\
\left({ }^{\circ} \mathrm{C}\right)\end{array}$ & $\begin{array}{c}\text { Specific } \\
\text { Condua- } \\
\text { tance } \\
\langle\alpha S / \mathrm{cm}\rangle\end{array}$ & $\begin{array}{c}\text { Dissolvad } \\
\text { Oxygen } \\
\text { (mg/) }\end{array}$ & $\begin{array}{l}\text { Dlseolved } \\
\text { Oxygen (\% } \\
\text { saturation) }\end{array}$ & or & $\begin{array}{c}\text { Total } \\
\text { Alkaltnity } \\
\text { (mg/ as } \\
\left.\mathrm{CaCO}_{3}\right)\end{array}$ & $\begin{array}{c}\text { Total } \\
\text { Herdness } \\
\text { (ma/l as } \\
\left.\mathrm{CaCO}_{0}\right)\end{array}$ \\
\hline Gleoler $\mathrm{Cr}_{\text {., site } 1}$ & $4-14-93$ & 1.3 & 109 & 15.2 & $10 B$ & 8.0 & & \\
\hline Glacier Cr., site 2 & $9-1-92$ & 6.0 & 90 & 12,8 & 103 & 7.5 & $3 B .3$ & 58 \\
\hline Glaoiar Cr, site 3 & $12-9 \cdot 92$ & -0.4 & 116 & 14.3 & 98 & 7.0 & & \\
\hline Giacier $C_{r}$, site 4 & $4-14-93$ & 4.2 & 101 & 14.0 & 107 & 7.8 & & \\
\hline \multirow{2}{*}{ Winner Creok } & $8 \cdot 1.92$ & 5.9 & 70 & 13.0 & 105 & 7.5 & 30.8 & 48 \\
\hline & $4-14-93$ & 2.4 & 90 & 14.4 & 105 & 7.9 & & \\
\hline Crow Creak & 4- $14-93$ & 2.7 & 133 & 14.0 & 104 & 8.1 & & \\
\hline
\end{tabular}

- Site locetions: Glacier Creok, site 1: 100 foet upseream of Crow Craek confluenas

Glacier Crook, site 2: 100 faet upstream of Winner Creak confluenco

Glacier Creak, sife 3: 0.5 miles upstream of airstrip

Glacier Crook, site 4: at railroad bridge, 0.2 miles above mouth

Winner Creok: 350 feet upstream of Glacier Crask confluence

Crow Creak: 150 feet upstream of Glacier Creok confluence 
Suspended-sediment concentrations and turbidity are shown on table 8 . All three streams have extremely low suspended-sediment concentrations and turbidity during mid- and late winter; total suspended solids ranged from 0.10 to $3.4 \mathrm{mg} / \mathrm{l}$, and turbidity ranged from 0.10 to $1.6 \mathrm{NTU}$. In September, the suspended-sediment concentration was five times higher in Glacier Creek than in Winner Creek, $22.5 \mathrm{mg} / \mathrm{l}$ and $4.4 \mathrm{mg} / \mathrm{l}$, respectively. Likewise, turbidity was about seven times higher in Glacier Creek than Winner Creek in September. There is a significant difference between field-measured and laboratory-measured turbidity in Glacier Creek for the September sampling period. This difference indicates the inaccuracy of dip samples when suspended sediment and turbidity are present in the stream. Therefore, the suspended sediment and turbidity values for Glacier Creek in September should be regarded as estimates.

Table 8. Summary of total suspended sediment and turbidity data collected in autumn, mid-winter, and late winter for streams in the project area.

\begin{tabular}{|c|c|c|c|c|c|c|c|}
\hline \multirow[b]{3}{*}{ Stream site' } & \multicolumn{3}{|c|}{ Total Suspended Solids (mg/l) } & \multicolumn{4}{|c|}{ Turbidity (NTU) } \\
\hline & \multirow{2}{*}{$\begin{array}{l}\text { Sept. } \\
1992\end{array}$} & \multirow{2}{*}{$\begin{array}{l}\text { Dec. } 1992 \\
\text { Jan. } 1993\end{array}$} & \multirow{2}{*}{$\begin{array}{l}\text { April } \\
1993\end{array}$} & \multicolumn{2}{|c|}{ Sept. 1992} & \multirow{2}{*}{$\begin{array}{l}\text { Dec. } 1992 \\
\text { Jan. } 1993\end{array}$} & \multirow{2}{*}{$\begin{array}{l}\text { April } \\
1993\end{array}$} \\
\hline & & & & Onsite & Lab & & \\
\hline Glacier Creek, site 1 & & 0.2 & 0.2 & & & 0.70 & 0.65 \\
\hline Glacier Creek, site 2 & 22.5 & & & 23 & 8.7 & & \\
\hline Glacier Creek, site 3 & & $\begin{array}{c}0.10 \\
0.3\end{array}$ & & & & $\begin{array}{l}0.63 \\
0.40\end{array}$ & \\
\hline Glacier Creek, site 4 & & & 0.4 & & & & 0.80 \\
\hline Winner Creek & 4.4 & 0.1 & 0.1 & 3.4 & 1.2 & 0.40 & 0.10 \\
\hline Crow Creek & & 0.3 & 3.4 & & & 0.70 & 1.6 \\
\hline
\end{tabular}

1 Site focations: Glacier Creek, site 1: 100 feet upstream of Crow Creek confluence Glacier Creek, site 2: 100 feet upstream of Winner Creek confluence Glacier Creek, site 3: 0.5 miles upstream of airstrip Glacier Craek, site 4: at railroad bridge, 0.2 miles above mouth Winner Creek: 350 feet upstream of Glacier Creek confluence Crow Creek: 150 feet upstream of Glacier Creek contiuence

The results of the laboratory analyses for water samples collected from Glacier and Winner Creoks is shown in table 9. Complete analytical reports and a key to sample numbers are given in Appendix B. Listed concentrations are "dissolved", unless otherwise noted.

Both streams have low mineralization; total dissolved solid concentrations are less than $60 \mathrm{mg} / \mathrm{L}$ (table 9\}. Aluminum, iron, and manganese are the only laboratory-analyzed inorganic constituents that exceed maximum contaminant concentration levels listed in the Alaska Drinking Water Regulations (Alaska Department of Environmental Conservation, 1993). 
Table 9. Results from laborazory analyses for inorganic constituents. Water samples were collected on September 1, 1992. All concentrations reported in milligrams per liter (mg/l).

\begin{tabular}{|c|c|c|c|c|}
\hline $\begin{array}{l}\text { Constituent } \\
\text { or property }\end{array}$ & Form & Glacier Creek & Winner Creek & MCL' \\
\hline Aluminum & $\begin{array}{c}\text { total } \\
\text { dissolved }\end{array}$ & $\begin{array}{r}1.28 \\
0.50 \\
\end{array}$ & $\begin{array}{l}0.76 \\
0.24\end{array}$ & 0.2 \\
\hline Arsenic & $\begin{array}{c}\text { total } \\
\text { dissolved }\end{array}$ & $\begin{array}{l}0.011 \\
0.008\end{array}$ & $\begin{array}{l}0.004 \\
0.004\end{array}$ & 0.05 \\
\hline Barium & $\begin{array}{c}\text { total } \\
\text { dissolved }\end{array}$ & $\begin{array}{l}0.04 \\
0.04\end{array}$ & $\begin{array}{l}0.01 \\
0.01\end{array}$ & 2 \\
\hline Cadmium & $\begin{array}{c}\text { total } \\
\text { dissolved }\end{array}$ & $\begin{array}{l}<0.001 \\
<0.001\end{array}$ & $\begin{array}{l}<0.001 \\
<0.001\end{array}$ & 0.006 \\
\hline Calcium & dissolved & 16.6 & 12.8 & \\
\hline Chloride & dissolved & 3.62 & 2.59 & 250 \\
\hline Chromium & $\begin{array}{c}\text { total } \\
\text { dissolved }\end{array}$ & $\begin{array}{l}<0.001 \\
<0.001\end{array}$ & $\begin{array}{l}<0.001 \\
<0.001\end{array}$ & 0.1 \\
\hline Copper & $\begin{array}{c}\text { total } \\
\text { dissolved }\end{array}$ & $\begin{array}{l}0.028 \\
0.003\end{array}$ & $\begin{array}{r}0.009 \\
<0.001\end{array}$ & 1.0 \\
\hline Fluoride & dissolved & 0.28 & 0.23 & 2.0 \\
\hline Iron & $\begin{array}{c}\text { total } \\
\text { dissolved }\end{array}$ & $\begin{array}{l}1.27 \\
0.55\end{array}$ & $\begin{array}{l}0.27 \\
0.14\end{array}$ & 0.3 \\
\hline Lead & $\begin{array}{c}\text { total } \\
\text { oissolved }\end{array}$ & $\begin{array}{l}<0.001 \\
<0.001 \\
\end{array}$ & $\begin{array}{l}<0.001 \\
<0.001 \\
\end{array}$ & (footnote 2) \\
\hline Magnesium & dissolved & 2.37 & 1.40 & \\
\hline Manganese & $\begin{array}{c}\text { total } \\
\text { dissolved }\end{array}$ & $\begin{array}{r}0.06 \\
<0.01\end{array}$ & $\begin{array}{l}<0.01 \\
<0.01\end{array}$ & 0.05 \\
\hline Nickel & $\begin{array}{c}\text { total } \\
\text { dissolved }\end{array}$ & $\begin{array}{l}<0.01 \\
<0.01 \\
\end{array}$ & $\begin{array}{l}<0.01 \\
<0.01 \\
\end{array}$ & 0.1 \\
\hline Nitrate + Nitrite & dissolved & $<0.1$ & 0.2 & 10 \\
\hline Potassium & dissolved & 0.95 & 0.87 & \\
\hline Silicon & $\begin{array}{c}\text { total } \\
\text { dissolved }\end{array}$ & $\begin{array}{l}3.58 \\
2.46 \\
\end{array}$ & $\begin{array}{l}1.83 \\
1.58 \\
\end{array}$ & \\
\hline Sodium & dissolved & 2.21 & 1.83 & 250 \\
\hline Sulfate & dissolved & 8.53 & 4.64 & 250 \\
\hline Total dissalved solids ${ }^{3}$ & & 58 & 44 & 500 \\
\hline Zinc & $\begin{array}{c}\text { total } \\
\text { dissolved }\end{array}$ & $\begin{array}{l}<0.02 \\
<0.02\end{array}$ & $\begin{array}{l}0.04 \\
0.02\end{array}$ & 5 \\
\hline
\end{tabular}

MCL = maximum contaminant level (State of Alaska Orinking Water Regulations, 18 AAC 80.070)

2 The lead action level is $0.015 \mathrm{mg} /$ INational Primary Drinking Water Regulations, 40 CFA 141, July 1 , 1992)

3 Computed value, based on the sum of dissoived-constituent concentrations.

Note: Shaded area $=$ constituent concentration exceeds the MCL 
The total concentrations for aluminum, iron, and manganese are slightly higher than the dissolved concentrations because these constituents are probably major components of the suspended sediment. The suspended sediment is digested, i.e. dissolved, with acid as part of the laboratory analysis, and therefore a part of the "total" concentration of these constituents.

A trilinear diagram is used to illustrate the chemical character or water type of a stream (Piper, 1944). Ratios of selected dissolved cations (calcium, magnesium, and sodium plus potassium) and anions (bicarbonate plus carbonate, chloride, ano sulfate) for each water analysis are shown in a trilinear diagram as percentages of the total cations and anions, in milliequivalents per liter (meq/l). Thus a water type can be described on the basis of predominant cations and anions found in the water. Glacier and Winner Creeks have water of the calcium bicarbonate type (fig. 3). These data indicate that the streams have similar geochemistry.

\section{Water-Quality Impacts}

Potential water-quality impacts to the quality of surface waters resulting from proposed development in the project area are shown in table 10. Water-quality impacts are presented as a "cause and effect" synopsis, along with mitigation measures to offset and minimize potential impacts.

The most probable water-quality impacts to streams in the project area are an increase in the suspended-sediment load and turbidity associated with land development and road construction. The potential for sediment runaff is high in the gorge area of Glacier, Crow, and Winner Creeks because of the precipitous terrain and shallow soils. Introduced suspended sediment will be most noticeable in late autumn and winter when streams are virtually free of glacial silt. Erosion and runotf control measures will be required to lessen impacts on surface waters. 


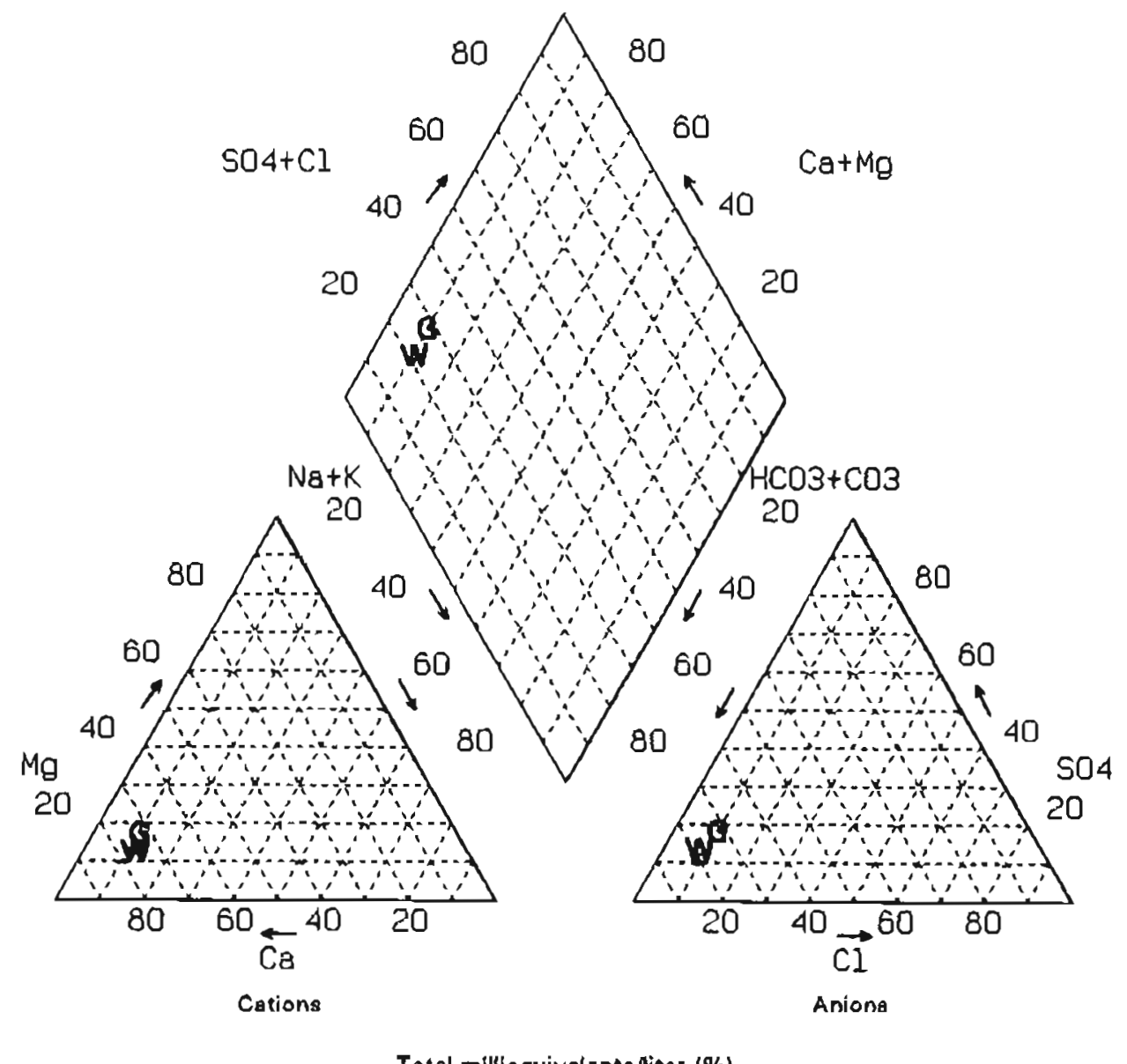

Total millequivalents/iter (\%)

\section{EXPLANATION}

Svmbol

G

w
Site

Glacier Creek

Winner Creek

\section{Water type}

Calcium bicarbonate

Calcium bicarbonate

Figure 3. Trilinear diagram showing water-type classification of water collected from Glacier and Winner Creoks on September 1, 1992. 


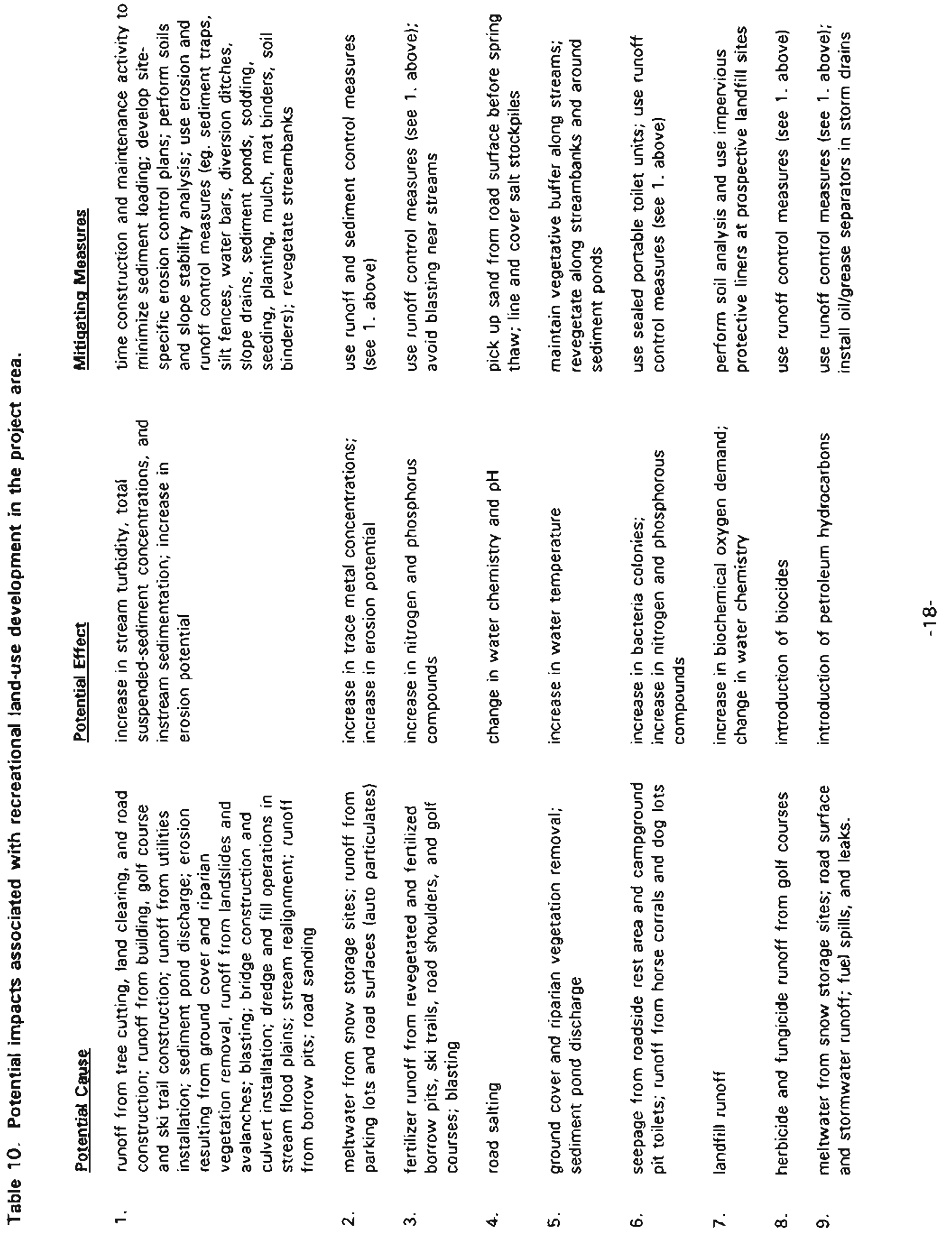




\section{CONCLUSIONS AND RECOMMENDATIONS}

(1) Weather data collected at the Alyeska Resort are transferrable to the Glacier/Winner Creek for general planning purposes. The primary need for additional weather data at the Glacier/Winner area is site-specific, longer term (2-5 years) wind data. More complete wind data would provide planners with a better understanding of snow movement, and wind direction and velocity. This information is useful for slope design, facility siting, and avalanche control.

(2) It is estimated that the proposed four-season resort in the GlacierMinner Creek area could require a maximum $534,000 \mathrm{gpd}(0.83 \mathrm{cfs}$ ) of water for domestic needs, and a maximum $360,000 \mathrm{gpd}(0.56 \mathrm{cfs})$ of water for snowmaking. Surface water from upper Glacier Creek, Crow Creek, and/or Winner Creek should easily satisfy these water needs from May through November. Prolonged cold, dry winter weather during periods of peak domestic and snowmaking demands could possibly reduce water supplies at other times of the year. The development of new water wells in the Glacier Creek alluvium downstream of the proposed resort could satisfy domestic needs, while surface water supplies from the Glacier/Winner Creek area could adequately meet snowmaking demands.

(3) This report presents a "snap-shot" look at the water quality of Glacier, Crow, and Winner Creeks near their confluence in the gorge. The majority of the historical data were collected at middle and lower Glacier Creek. No previous water-quality data have been collected for Crow Creek or Winner Creek.

(4) Total suspended sediment concentrations and turbidity are low in Glacier, Crow, and Winner Creeks during the winter. Total suspended-sediment data for spring breakup and summer storm events do not presently exist for the three streams above their confluence. The present sediment load contriburion of each stream should be documented prior to development. However, sampling difficulties are anticipated because of the highly turbulent streamflow during summer and the absence of bridges in the gorge from which to collect samples.

(5) The chemical water quality of Glacier and Winner Creeks at the gorge is good, based on the high dissolved oxygen content, basic $\mathrm{pH}$, and low total dissolved solid content of each stream. Prior to development, water analyses should be collected at high streamflow in mid-summer to completely document chemical water quality of each stream. These sampling sites can then be used as pre- and post-development water-quality monitoring stations.

16) Pre-and post-development monitoring of sediment and chemical water quality should be undertaken in lower Glacier Creek to access potential water-quality impacts associated with land development in the drainage basin.

\section{REFERENCES CITED}

Alaska Department of Environmental Conservation, 1993, State of Alaska Drinking Water Regulations 18 AAC 80.070: Alaska Department of Environmental Conservation, Juneau, Alaska, Title 18 Alaska Administrative Code Chapter 80.

Arctic Environmental Information and Data Center, 1986, Alaska climate summaries: Alaska Climate Center Technical Note Number 3, A.E.I.O.C., 470 p. 
American Public Health Association, American Water Works Association, Water Pollution Control Federation, 1989, Standard Methods for the Examination of Water and Wastewater, 17th edition: APHA, AWWA, WPCF, Washington, D.C.

Corps of Engineers, 1969, Flood plain information, Glacier Creek, Girdwood, Alaska: Corps of Engineers, U.S. Army, Alaska District, 43 p.

Glass, R.I., and Brabets, T.P., 1988, Summary of water resources data for the Girdwood-Alyeska area, Alaska: U.S. Geological Survey Open-File Report 87-678, 24 p.

Hem, J.D., 1985, Study and interpretation of the chemical characteristics of natural water (3rd ed.): U.S. Geological Survey Water-Supply Paper 2254, 263 p.

Hydrolab Corporation, 1981, Operation and maintenance instructions Hydrolab digltał 4041 , Austin, TX, $28 \mathrm{p}$.

Lamke, R.D., 1979, Flood characteristics of Alaskan streams: U.S. Geological Survey Water Resources Investigations 78-129,61 p.

Municipality of Anchorage, 1993, Background information, community facilities and utilities, Girdwood area: Department of Community Planning and Development, $14 \mathrm{p}$.

Orsborn, J.F., and Storm, M.C., 1991, R10 flowmods, hydrologic models for estimating ungaged streamflows on the Tongass and Chugach National Forests in south-east and south-central Alaska: Dept. of Civil and Enviranmental Engineering, Washington State University, $150 \mathrm{p}$.

Piper, A.M., 1944, A graphic procedure in the geochemical interpretation of water analyses: Transactions of the American Geophysical Union, v. 25, p. 914-923.

Seibu Alaska, 1991, Alyeska Resort master pian: Seibu Alaska, Inc., p. 5-11. 1993, Personal communication: Mountain Operations and Planning, $1 p$.

Sno.engineering, 1993, Evaluation of alternatives for resort development in the Glacier/Winner Creek area: Sno.engineering, Inc., Bellevue, Washington, $20 \mathrm{p}$.

Soil Conservation Service, 1993, Alaska annual data summary, water year 1992: U.S. Dept. of Agriculture, Soil Conservation Service, $22 \mathrm{p}$.

Stumm, W., and Morgan, J.J., 1981, Aquatic chemistry: an introduction emphasizing chemical equilibria in natural waters: John Wiley \& Sons, NY, 780 p.

U.S. Environmental Protection Agency, 1983, Methods for chemical analysis of water and wastes: U.S. Environmental Protection Agency, EPA-600/4-79-020, 1 volume, revised March 1983.

U.S. Forest Service, 1986, Climatic evaluation of potential winter sports development sites on the Chugach National Forest: U.S. Dept. of Agriculture, Forest Service, Alaska Region, 44p.

U.S. Geological Survey, 1958a, Quantity and quality of surface waters of Alaska, October 1950 to September 1953: U.S. Geological Survey Water-Supply Paper 1466, 243 p.

1958b, Quantity and quality of surface waters of Alaska, October 1953 to September 1956: U.S. Geological Survey Water-Supply Paper 1486, 229 p. 
U.S. Geological Survey, 1967, Water resources data for Alaska, 1966, part 2. Water quality records: U.S.Geological Survey water-data report, 81 .

1968. Water resources data for Alaska, 1967, part 2. Water quality records: U.S. Geological Survey water-data repon, $64 \mathrm{p}$.

, 1969, Water resources data for Alaska, 1968, part 2. Water quality records: U.S. Geological Survey water-data report, $99 \mathrm{p}$.

. 1971a, Water resources data for Alaska, 1969, part 2. Water quality records: U.S, Geological Survey water-data report, $71 \mathrm{p}$.

, $1971 \mathrm{~b}$, Water resources data for Alaska, 1970: U.S. Geological Survey water-data report, $263 \mathrm{p}$.

, 1972, Water resources data for Alaska, 1971: U.S. Geological Survey water-data report, $318 \mathrm{p}$.

1973, Water resources data for Alaska, 1972: U.S. Geological Survey water-data report, $387 \mathrm{p}$.

,1974, Water resources data for Alaska, 1973: U.S. Geological Survey, water-data report, $298 \mathrm{p}$.

1975, Water resources data for Alaska, 1974: U.S. Geological Survey water-data report, $322 \mathrm{p}$.

, 1977a, National hanobook of recommended methods for water-data acquisition: U.S.

Geological Survey, Office of Water Data Coordination, Reston, VA, 2 volumes.

, 19776, Water resources data for Alaska, water year 1976: U.S. Geological Survey Water-Data Report AK-76-1, 401 p.

, 1979, Water resources for Alaska, water vear 1978: U.S. Geological Survey WaterData Report AK-78-1, $425 \mathrm{p}$.

, 1986, Water resources data for Alaska, water vear 1985: U.S. Geological Survey Water-Data Report AK-85-1, 328 p.

1988, Water resources data for Alaska, water year 1986: U.S. Geological Survey Water-Data Report AK-86-1, 338 p.

Waring, 1993, Draft Girdwood community impact study: Kevin Waring Associates,

Transport/Pacific Associates, HOR Engineering, Inc., F. Don Vogan, ASLA, 198 p.

Zenone, Chester, 1974, Geology and water resources of the Girdwood-Alyeska area: U.S. Geological Survey Open-File Report (unn), 24 p. 
APPENDIX A. GLACIER CREEK DRAINAGE BASIN STREAMFLOW DATA

Mean Monthly Flow Estimates (cfs)

\begin{tabular}{l|c|c|c|c|c|c|c|c|c|c|c|c|c|c} 
& Jan & Feb & Mar & Apr & Mav & Jun & Jul & Aug & Sep & Oct & Nov & Dec & Mean \\
\hline $\begin{array}{l}\text { Glacier } \\
\text { Creek \#1 }\end{array}$ & 14 & 14 & 8.5 & 16 & 78 & 155 & 157 & 123 & 110 & 68 & 35 & 19 & 66 \\
\hline $\begin{array}{l}\text { Crow } \\
\text { Creek }\end{array}$ & 12 & 12 & 7.3 & 14 & 68 & 133 & 135 & 106 & 94 & 58 & 30 & 16 & 57 \\
$\begin{array}{l}\text { Winner } \\
\text { Creek }\end{array}$ & 12 & 12 & 7.3 & 14 & 68 & 133 & 135 & 106 & 94 & 58 & 30 & 16 & 57
\end{tabular}

Note: The above figures are based on USGS (1965-1978) mean monthly runoff data compiled for the USGS Glacier Creek gage site and extrapolated to the upstream tributary drainage basins. Crow and Winner Creeks have the same data because their respective basin areas are nearly equal.

Hydrologic Model Flow Calculations (cfs)

\begin{tabular}{|c|c|c|c|c|c|c|c|c|c|c|c|c|c|}
\hline & Jan & Feb & Mar & Apr & May & Jun & اuل & $\mathrm{Aug}$ & Sep & Oct & Nov & Dec & Mean \\
\hline $\begin{array}{l}\overline{\text { Glacier }} \\
\text { Creek } \# 1\end{array}$ & 22 & 16 & 14 & 19 & 68 & 153 & 124 & 83 & 79 & 60 & 50 & 29 & 60 \\
\hline $\begin{array}{l}\text { Crow } \\
\text { Creek }\end{array}$ & 18 & 14 & 12 & 16 & 58 & 131 & 106 & 71 & 68 & 52 & 42 & 25 & 51 \\
\hline $\begin{array}{l}\text { Winner } \\
\text { Creek }\end{array}$ & 17 & 13 & 12 & 15 & 55 & 122 & 99 & 67 & 63 & 48 & 40 & 23 & 48 \\
\hline
\end{tabular}

Note: The hydrologic model flow calculations are based on Orsborn and Storm's (1991) "R10" straamflow model. Figures are derived from basin areas and elevations. 
APPENDIX B

Laboratory Water-Quality Analytical Reports

Water samples analyzed by Alaska Hydrologic Survey, Water Quality Laboratory, Fairbanks, Alaska All inorganic constituent concentrations are dissolved, unless otherwise noted.

$\mathrm{DL}=$ detection limit

$\mathrm{RPD}=$ relative percent difference

KEY TO BOTTLE NUMBERS

OF WATEA SAMPLES COLLECTED ON $9 / 4 / 92$

\section{Analysis}

Turbidity, total suspended solids, and total dissolved solids

Anions $\left(\mathrm{F}, \mathrm{Cl}, \mathrm{SO}_{4}\right)$

Nitrate + Nitrite

Cations $(\mathrm{Ca}, \mathrm{Mg}, \mathrm{Na}, \mathrm{K}$ ),

and dissolved trace elements

Total trace elements
Bottle Number

624

625

207

208

246

247

233

234

220

221
Stream

Winner Creek Glacier Creek, site 2

Winner Creek

Glacier Creek, site 2

Winner Creek

Glacier Creek, site 2

Winner Creek

Glacier Croek, site 2

Winner Creek

Glacier Creek, site 2 


\section{Department of Natural Resources / Division of $\mathrm{W}$ ater

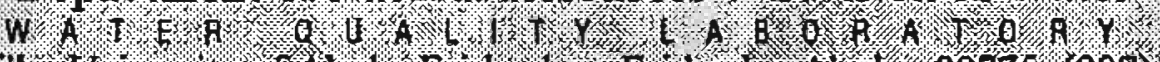

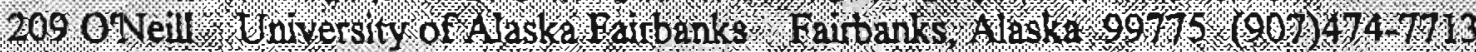

Client: DNR/DOW Eagle River

Submitted By: Mary Maurer

Date Submitted: September 1992

\begin{tabular}{cccc|}
\hline Sample & Turbidity & Total Suspended Solids & Total Dissolved Solids \\
\hline & & & \\
624 & 1.2 & 4.42 & 44 \\
& 8.7 & 22.5 & 58 \\
Units & NTU & mg/L & $\mathrm{mg} / \mathrm{L}$ \\
EPA Method & 180.1 & 160.2 & $* \mathbf{2}$ \\
Detection Limit & 0.1 & 0.1 & - \\
Date of Analysis & 8 Oct 92 & 8 Oct 92 & - \\
RPD & - & - & - \\
\% Recovery & - & - & \\
\hline
\end{tabular}

** by calculation using USGS method I-175I-78

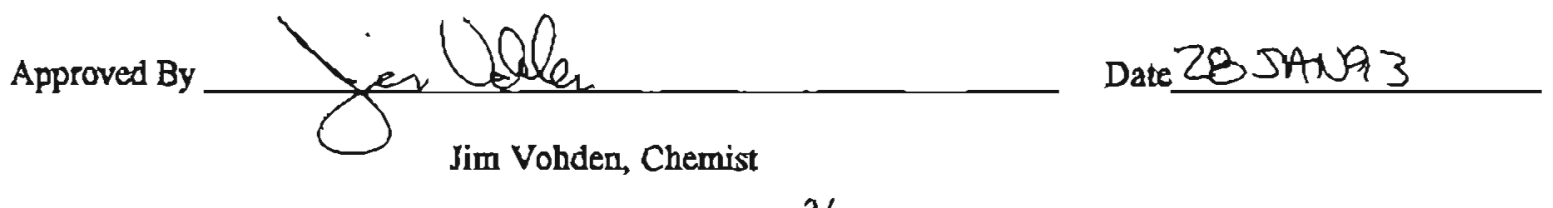

$$
-24-
$$


Client: DNR/DOW Eagle River

Submitted By: $\quad$ Mary Maurer

Date Submitted: September 1992

\begin{tabular}{cccc|}
\hline Sample & Fluoride & Chloride & Sulfate \\
\hline 207 & 0.23 & & \\
208 & 0.28 & 2.59 & 4.64 \\
& & 3.62 & 8.53 \\
Units & $\mathrm{mg} / \mathrm{L}$ & $\mathrm{mg} / \mathrm{L}$ & $\mathrm{mg} / \mathrm{L}$ \\
EPA Method & 340.2 & 300.0 & 300.0 \\
Detection Linit & 0.01 & 0.01 & 0.01 \\
Date of Analysis & 25 Sept 92 & 25 Sept 92 & 25 Sept 92 \\
RPD & 5.4 & 2.7 & 8.6 \\
\% Recovery & 101 & 92 & 91 \\
\hline
\end{tabular}

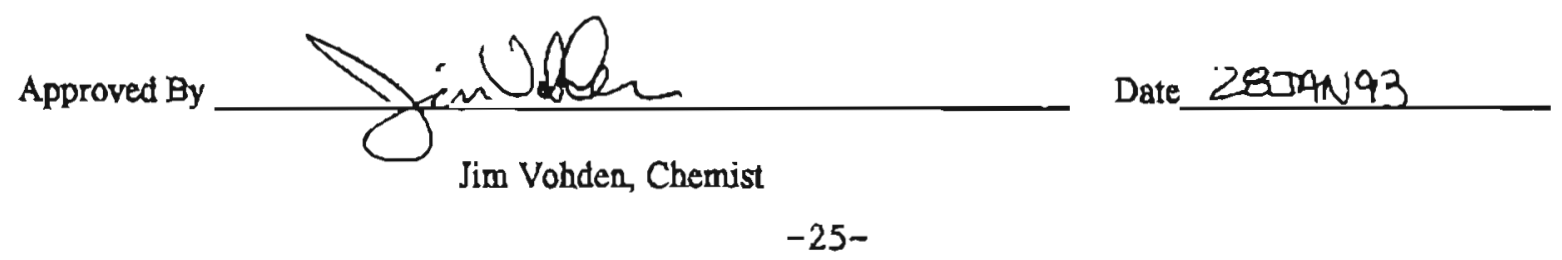




\section{Stace or Aaska}

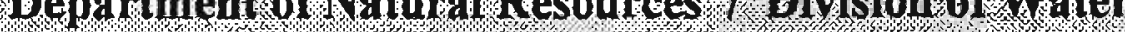

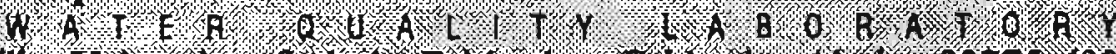

Client: DNRDOW Eagle River

Submitted By: Mary Maurer

Date Submitted: September 1992

\begin{tabular}{cc|}
\hline Sample & Nitrate + Nitrite \\
\hline & \\
246 & 0.2 \\
247 & $<\mathrm{DL}$ \\
Units & $\mathrm{mg} / \mathrm{L}$ as N \\
EPA Method & 353.2 \\
Detection Limit & 0.1 \\
Date of Analysis & $25 \mathrm{Sept} 92$ \\
RPD & 6.5 \\
\% Recovery & 92 \\
\hline
\end{tabular}

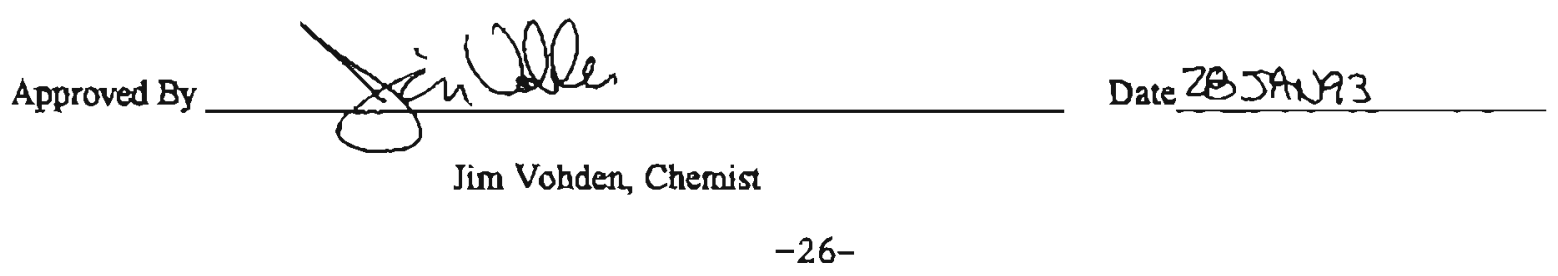




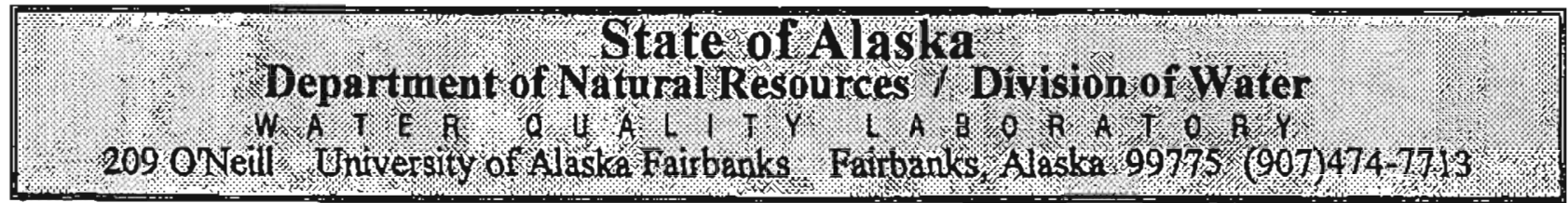

Client: DNR/DOW Eagle River

Submitted By: Mary Maurer

Date Submitted: September 1992

\begin{tabular}{ccccc|}
\hline Sample & Calcium & Magnesium & Sadium & Potassium \\
\hline 233 & 12.8 & & & \\
234 & 16.6 & 1.40 & 1.83 & 0.87 \\
& & 2.37 & 2.21 & 0.95 \\
Units & $\mathrm{mg} / \mathrm{L}$ & $\mathrm{mg} / \mathrm{L}$ & $\mathrm{mg} / \mathrm{L}$ & $\mathrm{mg} / \mathrm{L}$ \\
EPA Method & AES 0029 & AES 0029 & AES 0029 & 258.1 \\
Detection Limit & 0.01 & 0.02 & 0.1 & 0.01 \\
Date of Analysys & 26 Oct 92 & 26 Oct 92 & 26 Oct 92 & 26 Oct 92 \\
RPD & 0.7 & 0.5 & 16.4 & 4.9 \\
\% Recovery & 101 & 99 & 102 & 109 \\
& & & & \\
\hline
\end{tabular}

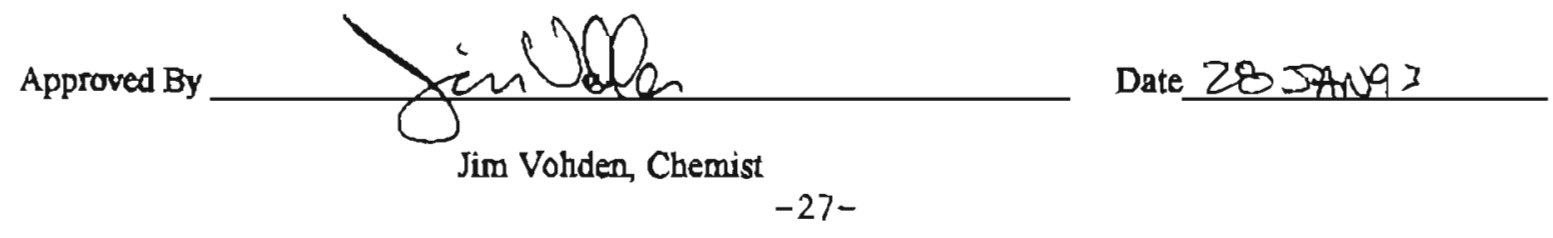




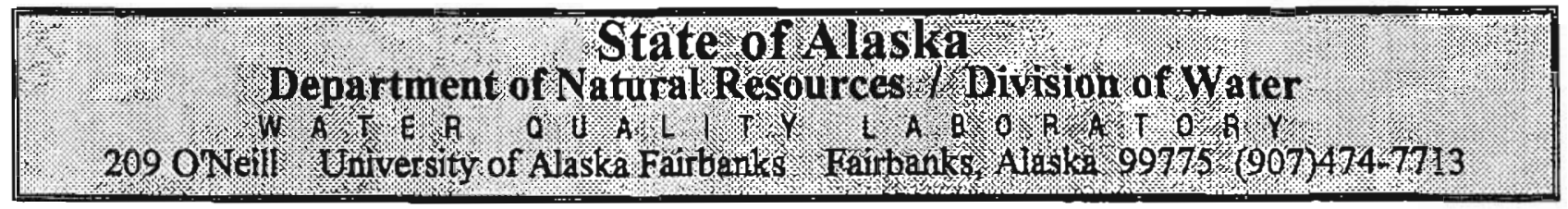

Client: DNRDOW Eagle River

Submitted By: Mary Maurer

Date Submitted: September 1992

\begin{tabular}{cccccc|}
\hline Sample & Iron & Manganese & Aluminum & Barium & Nickel \\
233 & 0.14 & & & & \\
234 & 0.55 & $<\mathrm{DL}$ & 0.24 & 0.01 & $<\mathrm{DL}$ \\
& & & 0.50 & 0.04 & $<\mathrm{DL}$ \\
Units & $\mathrm{mg} / \mathrm{L}$ & $\mathrm{mg} / \mathrm{L}$ & $\mathrm{mg} / \mathrm{L}$ & $\mathrm{mg} / \mathrm{L}$ & $\mathrm{mg} / \mathrm{L}$ \\
EPA Method & AES 0029 & AES 0029 & AES 0029 & AES 0029 & AES 0029 \\
Detection Limit & 0.03 & 0.01 & 0.01 & 0.01 & 0.01 \\
Date of Analysis & 23 Oct 92 & 23 Oct 92 & 23 Oct 92 & 23 Oct 92 & 23 Oct 92 \\
RPD & 0.0 & 2.0 & 5.3 & 6.3 & 4.7 \\
\% Recovery & 97 & 101 & 104 & 90 & 92 \\
& & & & & \\
\hline
\end{tabular}

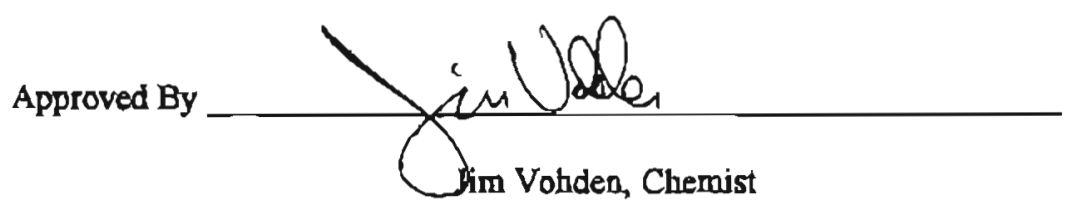

Date 28540193 


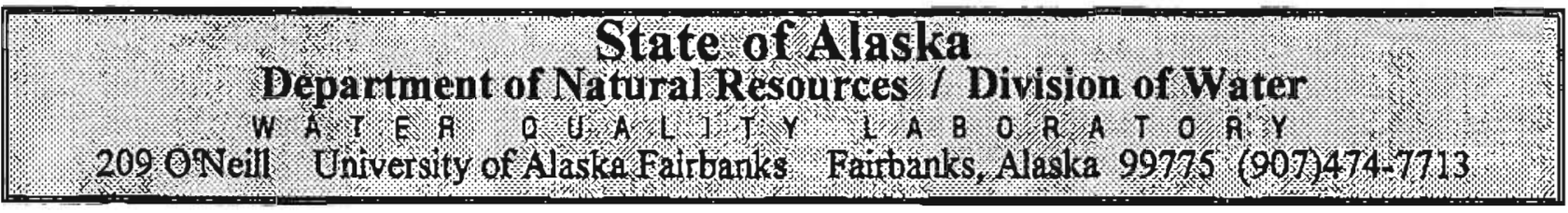

Client: DNRDOW Eagle River

Submitted By: Mary Maurer

Date Submitted: September 1992

\begin{tabular}{cccccc|}
\hline Sample & Silicon & Zinc & Arsenic & Cadmium & Chromium \\
\hline 233 & 1.58 & 0.02 & 0.004 & $<\mathrm{DL}$ & $<\mathrm{DL}$ \\
234 & 2.46 & $<\mathrm{DL}$ & 0.008 & $<\mathrm{DL}$ & $<\mathrm{DL}$ \\
& & & & & \\
Units & $\mathrm{mg} / \mathrm{L}$ & $\mathrm{mg} / \mathrm{L}$ & $\mathrm{mg} / \mathrm{L}$ & $\mathrm{mg} / \mathrm{L}$ & $\mathrm{mg} / \mathrm{L}$ \\
EPA Method & AES 0029 & AES 0029 & 206.2 & 213.2 & 218.2 \\
Detection Limit & 0.01 & 0.02 & 0.001 & 0.001 & 0.001 \\
Date of Analysis & 23 Oct 92 & 23 Oct 92 & 22 Oct 92 & 22 Oct 92 & 22 Oct 92 \\
RPD & 2.0 & 3.5 & 1.8 & 3.7 & 2.2 \\
\% Recovery & 101 & 105 & 96 & 91 & 91 \\
& & & & & \\
\hline
\end{tabular}

Approved By

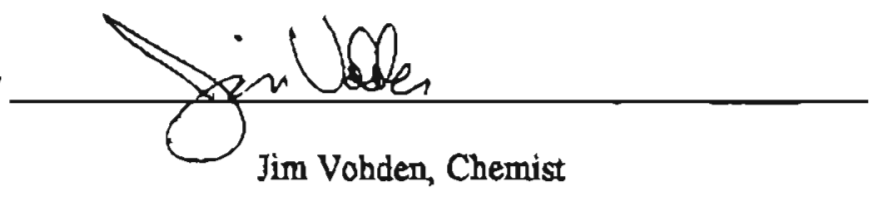

Date 283 SAN 93 


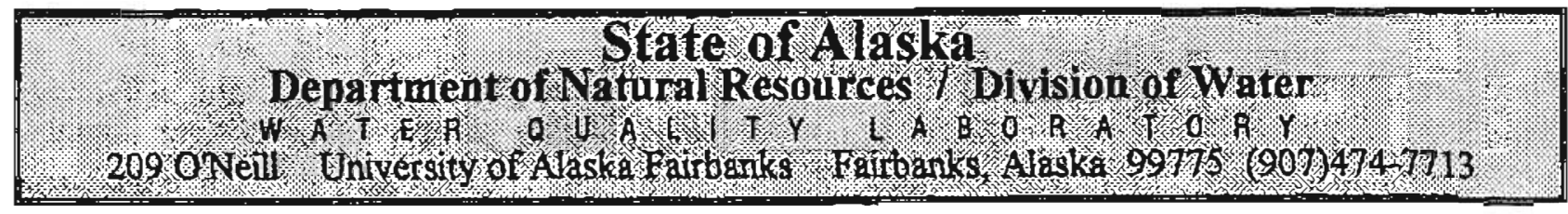

Client: DNR/DOW Eagle River

Submitted By: Mary Maurer

Date Submitted: September 1992

\begin{tabular}{ccc|}
\hline Sample & Copper & Lead \\
233 & $<\mathrm{DL}$ & $<\mathrm{DL}$ \\
234 & 0.003 & $<\mathrm{DL}$ \\
& & \\
Units & $\mathrm{mg} / \mathrm{L}$ & $\mathrm{mg} / \mathrm{L}$ \\
EPA Method & 220.2 & 239.2 \\
Detection Limit & 0.001 & 0.001 \\
Date of Analysis & 22 Oct 92 & 22 Oct 92 \\
RPD & 5.6 & 6.2 \\
\% Recovery & 107 & 94 \\
\hline
\end{tabular}

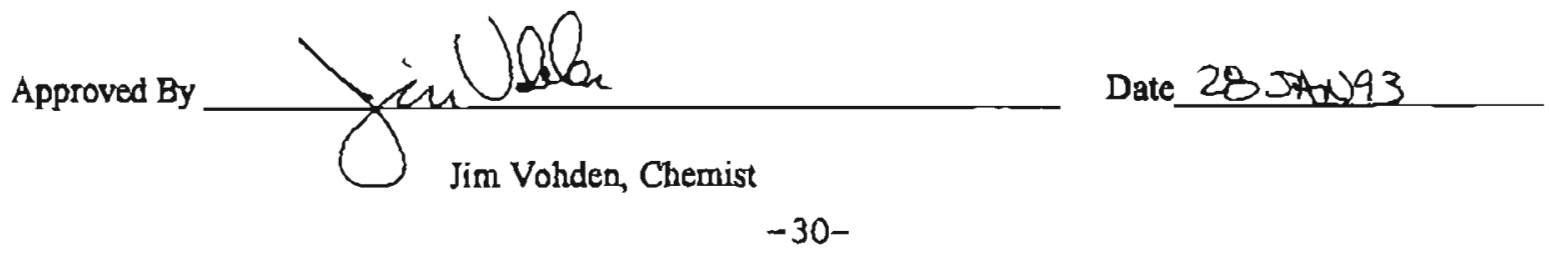




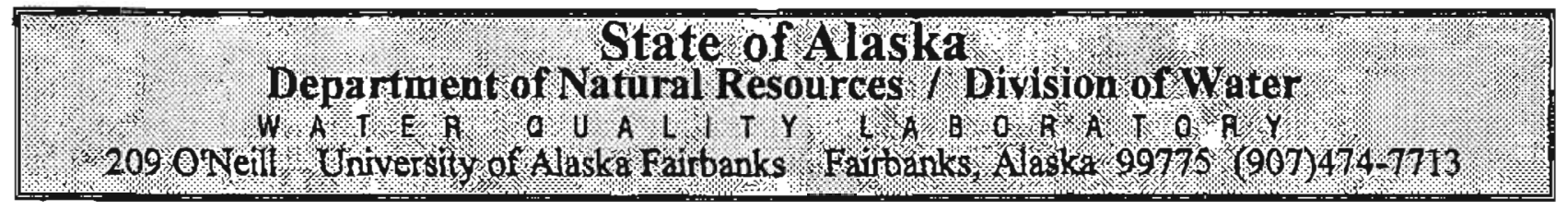

Client: DNRDOW Eagle River

Submitted By, Mary Maurer

Date Submitted: September 1992

\begin{tabular}{cccccc|}
\hline Sample & Iron(total) & Manganese(total) & Alurainum(total) & Barium(total) & Nickel(total) \\
220 & 0.27 & LDL & 0.76 & 0.01 & <DL \\
221 & 1.27 & 0.06 & 1.28 & 0.04 & $<\mathrm{DL}$ \\
Units & $\mathrm{mg/L}$ & $\mathrm{mg} / \mathrm{L}$ & $\mathrm{mg/L}$ & $\mathrm{mg} / \mathrm{L}$ & $\mathrm{mg} / \mathrm{L}$ \\
EPA Method & AES 0029 & AES 0029 & AES 0029 & AES 0029 & AES 0029 \\
Detection Limit & 0.03 & 0.01 & 0.01 & 0.01 & 0.01 \\
Date of Analysis & 23 Oct 92 & 23 Oct 92 & 23 Oct 92 & 23 Oct 92 & 23 Oct 92 \\
RPD & 3.7 & 2.2 & 6.5 & 1.1 & 5.7 \\
\% Recovery & 99 & 91 & 103 & 106 & 90 \\
& & & & & \\
\hline
\end{tabular}

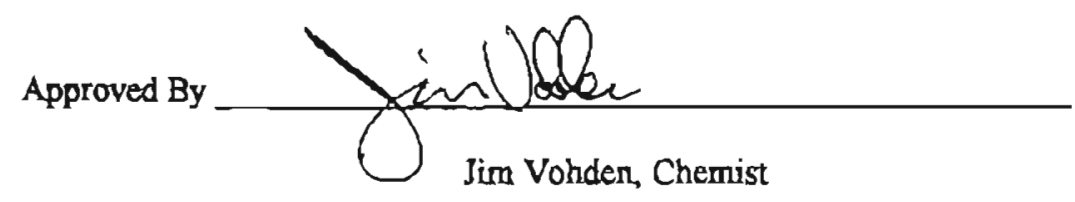

Date 2854093 


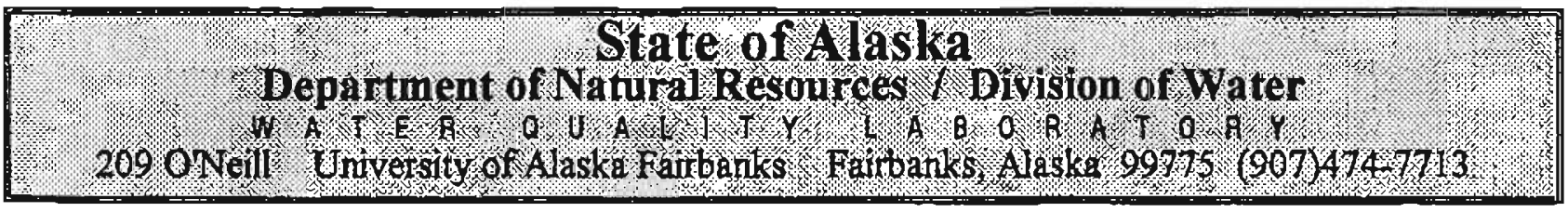

Client: DNRDOW Eagle River

Submitted By: Mary Maurer

Date Submitted: September 1992

\begin{tabular}{cccccc|}
\hline Sample & Silicon(total) & Zinc(total) & Arsenic(total) & Cadmium(total) Chromium(total) \\
\hline 220 & 1.83 & 0.04 & 0.004 & $<\mathrm{DL}$ & $<\mathrm{DL}$ \\
221 & 3.58 & $\mathrm{DLL}$ & 0.011 & $<\mathrm{DL}$ & $<\mathrm{DL}$ \\
Units & $\mathrm{mg} / \mathrm{L}$ & $\mathrm{mg} / \mathrm{L}$ & $\mathrm{mg} / \mathrm{L}$ & $\mathrm{mg} / \mathrm{L}$ & $\mathrm{mg} / \mathrm{L}$ \\
EPA Method & AES 0029 & AES 0029 & 206.2 & 213.2 & 218.2 \\
Detection Limit & 0.01 & 0.02 & 0.001 & 0.001 & 0.001 \\
Date of Analysis & 23 Oct 92 & 23 Oct 92 & 22 Oct 92 & 22 Oct 92 & 22 Oct 92 \\
RPD & 3.3 & 8.5 & 3.4 & 3.7 & 9.8 \\
\% Recovery & 92 & 103 & 94 & 91 & 95 \\
& & & & & \\
\hline
\end{tabular}

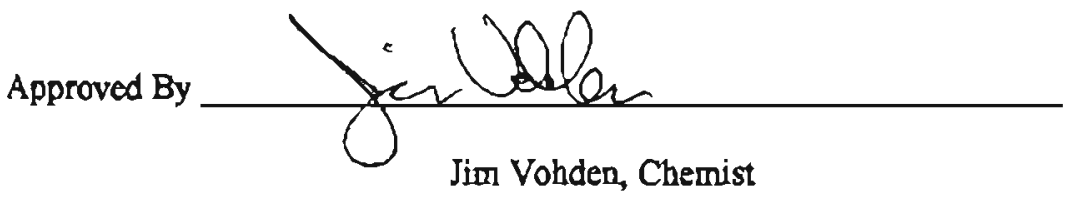

Date 28 JAN 93 


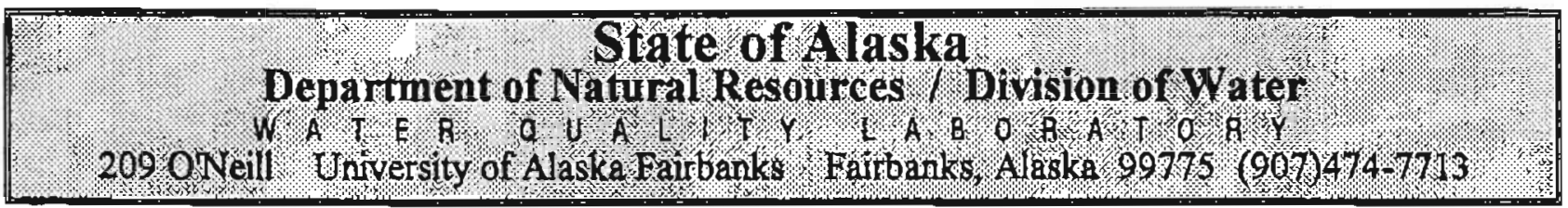

Client: DNR/DOW Eagle River

Submitted By: Mary Maurer

Date Submitted: September 1992

\begin{tabular}{|c|c|c|}
\hline Sample & Copper(total) & Lead(total) \\
\hline 220 & 0.009 & $<D L$ \\
\hline 221 & 0.028 & $\angle D L$ \\
\hline Units & $\mathrm{mgg} / \mathrm{L}$ & $\mathrm{mg} / \mathrm{L}$ \\
\hline EPA Method & 220.2 & 239.2 \\
\hline Detection Limit & 0.001 & 0.001 \\
\hline Date of Analysis & 22 Oct 92 & 22 Oct 92 \\
\hline RPD & 1.0 & 6.8 \\
\hline$\%$ Recovery & 104 & 94 \\
\hline
\end{tabular}

Approved By

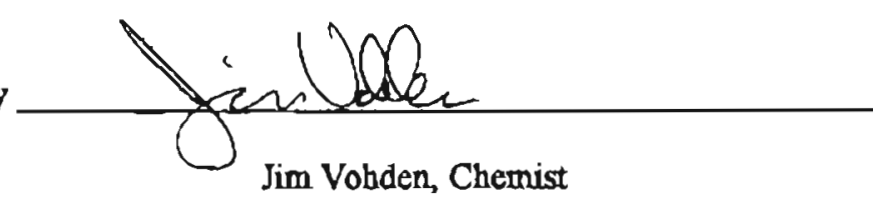

Date 28 SANA3 


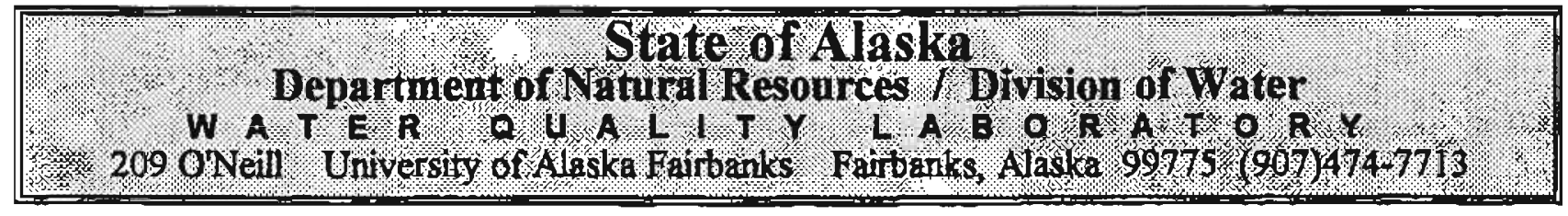

Client: ADNRDOW -- Eagle River

Submitted By: M. Maurer

Date / Time Sampled: 9 December 1992 / 1330

Date Submitted: 11 December 1992

\begin{tabular}{ccc|}
\hline Sample & Turbidity & Total Suspended Solids \\
\hline Glacier Creek & 0.63 & 0.10 \\
Units & NTU & $\mathrm{mg} / \mathrm{L}$ \\
EPA Method & 180.1 & 160.2 \\
Detection Limit & 0.10 & 0.10 \\
\hline
\end{tabular}

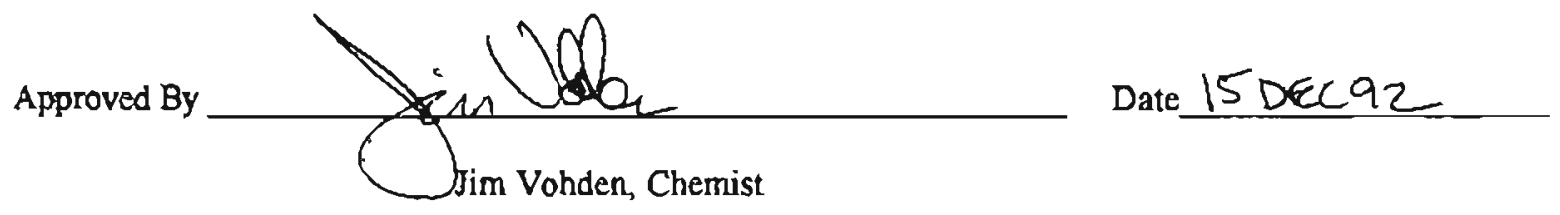




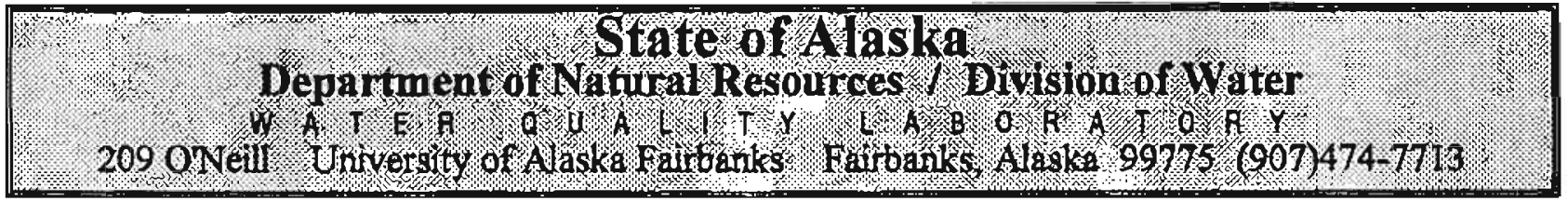

Client: DNRDOW -- Eagle River

Submitted By: Mary Maurer

Date Submitted: Jan 1993

\begin{tabular}{|c|c|c|c|c|}
\hline Sample & Date & Time & Turbidity & Total Suspended Solids \\
\hline Winner $\mathrm{Cr}$. & $13 \operatorname{Jan} 93$ & $12: 43$ & 0.40 & 0.10 \\
\hline Glacier C. ( $100 \mathrm{ft}$ above Crow $\mathrm{Cr}$ ) & $13 \operatorname{Jan} 93$ & $14: 10$ & 0.70 & 0.19 \\
\hline Crow Cr. & $13 \mathrm{Jan} 93$ & $14: 52$ & 0.70 & 0.29 \\
\hline Glacier Cr. (0.5 mi above airstrip) & $13 \operatorname{Jan} 93$ & $16: 15$ & 0.40 & 0.29 \\
\hline Units & & & NTU & $\mathrm{mg} / \mathrm{L}$ \\
\hline EPA Method & & & 180.1 & 160.2 \\
\hline Detection Limit & & & 0.05 & 0.1 \\
\hline RPD & & & -- & - \\
\hline$\%$ Recovery & & & - & - \\
\hline
\end{tabular}

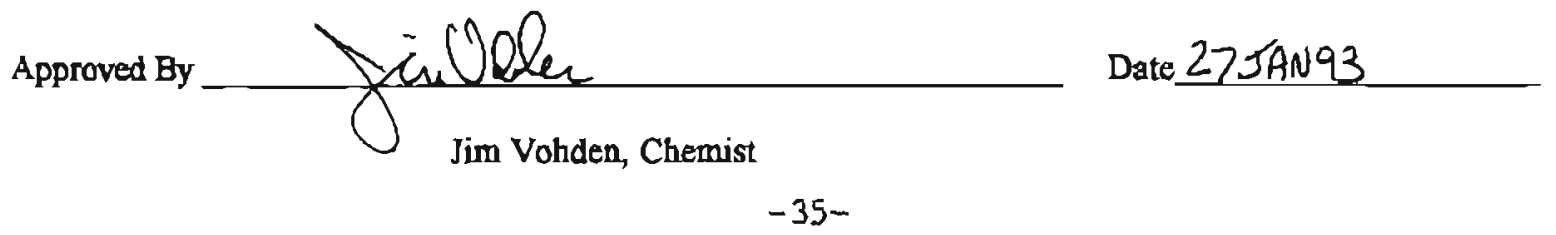




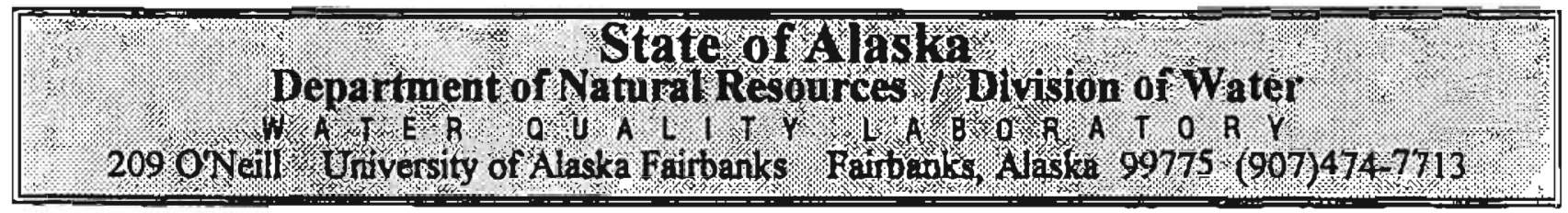

Client: DNR / Division of Water - Eagle River

Submitted By: Mary Maurer

Date Submitted: 16 April 1993

Sample Turbidity

Total Suspended Solids

\section{Upper Glacier $\mathrm{Cr}$}

Crow $\mathrm{Cr}$

Winner $\mathrm{Cr}$

Glacier Cr@ RR Bridge

Units

EPA Method

Detection Limit

RPD

\% Recovery

$\begin{array}{ll}0.65 & 0.20 \\ 1.6 & 3.4 \\ 0.10 & 0.10 \\ 0.80 & 0.43\end{array}$

NTU

$180.1 \quad 160.2$

$0.05 \quad 0.1$

-

Author's note: sample collected at 'Upper Glacter $\mathrm{Cr}^{\prime}$ ' is Glacler Creek, stte 1 gample collected at 'Glacier Cr e RR Bridge' is Glacier Creek, site 4

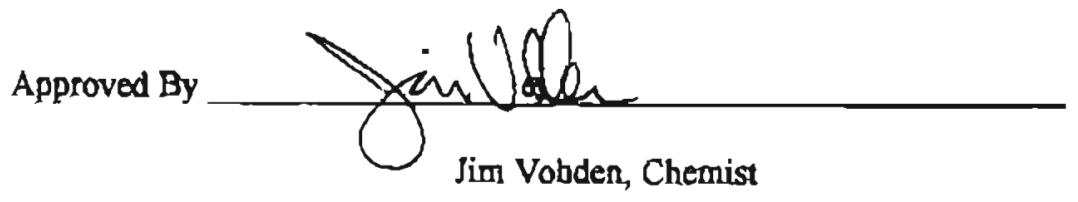

Date 27 APR93 